Technology Development and Applications Lead Center

\title{
Silicon Materials Outlook Study for 1980-85 Calendar Years
}

\author{
E. Costogue \\ R. Ferber \\ W. Hasbach \\ R. Pellin - Consultant, Charlotte, NC \\ C. Yaws - Consultant, Beaumont, TX
}

This book was prepared as an account of work sponsored by an agency of the United States Government.
Neither the United States Government nor any agency thereot, nor any of their employees, makes any
werranty, express or implied, or assumes any legal liability or responsibility for the accuracy,
completeness, or usefulness of any information, apparatus, product, or process disclosed, or
represents that its use would not infringe privately owwed rights, Reference herein to any specific
commercial product, process, or service by trade name, trademark, manufacturer, or otherwise, does
not necessarily constitute or imply its endorsement, recommendation, or favoring by the United
States Government or any agenecy thereot. The views and opinions of authors expressed herein do not
necessarily state or reflect those of the United States Government or any agency thereof.

\section{MASTER}

November 1, 1979

Prepared for

U.S. Department of Energy

Through an agreement with

National Aeronautics and Space Administration

by

Jet Propulsion Laboratory

California Institute of Technology

Pasadena, California

(JPL Publication 79-110) 


\section{DISCLAIMER}

This report was prepared as an account of work sponsored by an agency of the United States Government. Neither the United States Government nor any agency Thereof, nor any of their employees, makes any warranty, express or implied, or assumes any legal liability or responsibility for the accuracy, completeness, or usefulness of any information, apparatus, product, or process disclosed, or represents that its use would not infringe privately owned rights. Reference herein to any specific commercial product, process, or service by trade name, trademark, manufacturer, or otherwise does not necessarily constitute or imply its endorsement, recommendation, or favoring by the United States Government or any agency thereof. The views and opinions of authors expressed herein do not necessarily state or reflect those of the United States Government or any agency thereof. 


\section{DISCLAIMER}

Portions of this document may be illegible in electronic image products. Images are produced from the best available original document. 
Prepared by the Jet Propulsion Laboratory, California Institute of Technology, for the U.S. Department of Energy through an agreement with the National Aeronautics and Space Administration.

This report was prepared as an account of work sponsored by the United States Government. Neither the United States nor the United States Department of Energy, nor any of their employees, nor any of their contractors, subcontractors, or their employees, makes any warranty, express or implied, or assumes any legal liability or responsibility for the accuracy, completeness or usefulness of any information, apparatus, product or process disclosed, or represents that its use would not infringe privately owned rights. 
Photovoltaic solar cell arrays converting solar energy into electrical energy can become a cost-effective, alternative energy source provided that an adequate supply of low-priced solar cell materials and automated fabrication techniques are available.

Presently, the photovoltaic industry is dependent upon polycrystalline silicon which is produced primarily for integrated circuits, power devices, and the discrete semiconductor device industry. This dependency is expected to continue until DOE-sponsored new technology developments mature and the photovoltaic industry develops its own source of supply. Recent industry forecasts have predicted a limited supply of polycrystalline silicon material and a shortage could occur in the early $80^{\prime} \mathrm{s}$ due to increasing demands by the semiconductor integrated circuit and power device manufacturers.

The Jet Propulsion Laboratory's Technology Development and Application Lead Center formed an ad hoc committee of JPL, SERI and consultant personnel. The committee was to review the availability of silicon material, single crystal ingot growing and wafer slicing capabilities to meet the manufacturing needs of the photovoltaic industry during 19801985. The ad hoc committee conducted interviews with key polycrystalline manufacturers and a large cross-section of single crystal ingot growers and wafer manufacturers, silicon material equipment manufacturers, integrated circuit manufacturers and silicon solar cell manufacturers.

Industry consensus and conclusions reached from the analysis of the data obtained by the committee are summarized below:

- There is a high probability of polycrystalline silicon shortage by the end of CY 1982 and a strong seller's market after CY 1981 wlich will foster price competition for available silicon because of:

(1) The persistence of strong market demands by the integrated circuits industry.

(2) Any recession in the 1979-1980 period is not expected to have significant effect on demand based on previous recessions.

(3) Expansion of Siemens-process manufacturing capacity with new plants which has occurred in the past to meet market demands is now unlikely. Industry is convinced that:

(a) DOE-sponsored, low-cost processes are becoming commercially ready

(b) Polycrystalline silicon price from new Siemens plants is expected to be in excess of $\$ 100$ to compensate for investment. 
- Some capacity expansion of existing plants is possible (up to $20 \%$ expansion at a moderate increase in price). This will only delay the projected shortage by a few months.

- DOE-sponsored (LSA Project) new, polycrystalline silicon production processes have been proven technically feasible and, per present DOE plans, large-scale plants can be operational by 1986 .

- Single crystal ingot growing and wafer slicing plant capacity is and will remain in balance with the needs of the users.

- Advanced thin-film based photovoltaic cell processes will probably not be commercially ready before 1985 .

- Unless the polycrystalline industry spearheads new pruducliun techniques and processes to increase its capacity within the next 12 months, implementation of Public Law 95-590 wil1 require government involvement in sponsoring an expansion of polycrystalline silicon production capacity. Industry has stated that long-range procurement contracts will be needed before it will be willing to invest on its own.

This report summarizes the polycrystalline silicon, single-crystal ingot growing, and wafer slicing plant capacities, and market needs during 1980-1985. The report is limited in that proprietary information retained by the industry could modify the conclusions. Technological breakthroughs could take place earlier than anticipated, thereby substantially improving the potential for industry to develop the needed production capacity and to achieve the economic goals of the silicon solar array industry. Many plans which are proprietary within each affected company could impact the future silicon availability; but, for the present, it is necessary that any procurement planning consider the potential of a silicon shortfall in 1983 and the period beyond. 
I. INTRODUCTION ------
A. OBJECTIVE $1-1$
B. BACKGROUND $1-2$

II. MARKET FORECAST FOR POLYCRYSTALLINE SILICON

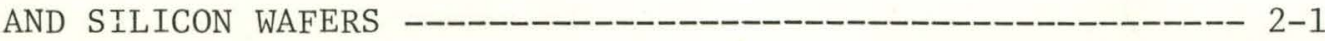
A. INTRODUCTION $2-1$

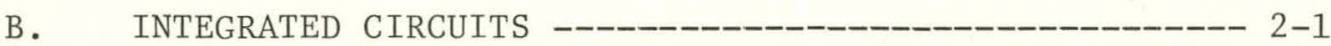
C. POWER DEVICES ---_-_-_- 2-4
D. PHOTOVOLTAIC SILICON SOLAR CELL ARRAYS ------------- 2-6

III. FREE WORLD EXISTING PLANT CAPACITY --_--

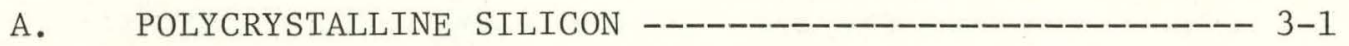

B. SINGLE CRYSTALS SILICON INGOTS AND WAFERS --------- 3-6

C. SINGLE CRYSTAL INGOT AND WAFERING. QUESTIONNAIRE REVIEW ----------------------------- 3-10

IV. COMPARISON OF CAPACITY AND MARKET NEEDS ------------ 4-1

A. POLYCRYSTALLINE SILICON --_-_-_-_-_-_-_

B. SINGLE CRYSTAL SILICON INGOTS AND WAFERS --------- 4-3

V. INFLUENCING ECONOMIC AND TECHNICAL FACTORS ------------- 5-1

A. ECONOMIC CONSIDERATION -

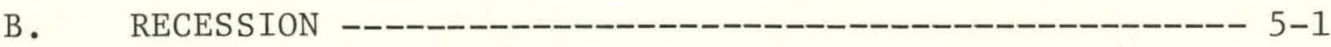

C. SIIEET SILICON CROWTH -

D. DIRECTIONAL SOLIDIFICATION OF SILICON ----------- 5-2

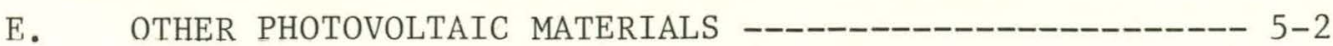

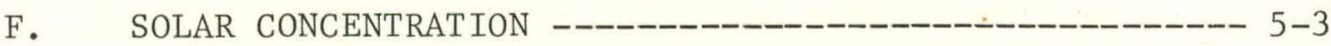


APPENDIX

A. STUDY TEAM ORGANIZATION AND PROCEDURES --

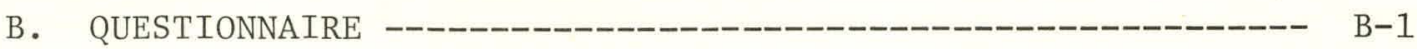

Figures

1-1. Polycrysta1line Market Over Calendar Years --_-------- 1-2

1-2. Single Crystal Ingot Market Over Calendar Years ------ 1-3

1-3. Silicon Wafer Market Over Calendar Years ------------ 1-3

2-1. The Free World InLegrated Circuit Market of Polished Silicon Slices for Integrated Circuits --------------- 2-2

2-2. Free World Market Forecast to 1985 of Single Crystal Silicon Ingots and Polycrystalline Silicon for

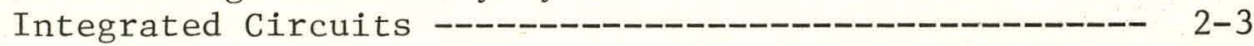

2-3. Free Wor1d Market Forecast to 1985 of Silicon Wafers for Power Devices --_- 2-4

2-4. Free World Market Forecast to 1985 of Single Crystal Silicon Ingots and Polycrystalline Silicon for Power Devices --_-_-_-_-_-_-_

2-5. Silicon Solar Cel1 Array Market Projections Based on the Solar Photovollaic Energy Research, Development and Demonstration Act of 1978, Medium, and Low Market Development Projections --_-_-_-_-_-_-_ 2-_

3-1. Polycrystalline Silicon Capacity Versus Year -------- 3-2

3-2. The Manufacturing Process Flow for a Typical Siemens Polycrystalline Silicon Plant -_-_-_-_ 3-4

3-3. Silicon Single Crystal Ingot Capacity Versus Year ---- 3-7

3-4. Silicon Wafer Capacity Versus Year ------------------ 3-8

4-1. Comparison of Market and Capacity for Polycrystalline Silicon (Without Solar) ------_----_---_------- 4-2

4-2. Current and Projected Polycrystal Material Supply and Demand Requirements -_-_-_-_-6 
4-3. Comparison of Market and Capacity for Silicon

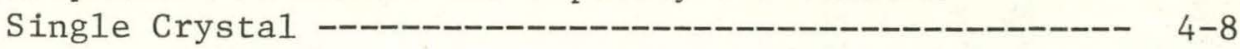

4-4. Comparison of Capacity and Market for Silicon Wafers - 4-10

6-1. Silicon Supply Scenario for the Solar Photovoltaic

Energy Research, Development and Demonstration Act

(Public Law 95-590) dated Nov 41978

$6-4$

Tables

2-1. Polycrystalline Silicon Requirement Per Polished

S1ice

$2-2$

2-2. Square Centimeters of Silicon Solar Cells Required to Produce One Peak Watt of Electrical Power for Various Solar Cell Efficiencies $\left(100 \mathrm{w} / \mathrm{m}^{2}\right.$

Insolation)

2-3. Market Forecast for Silicon Solar Ce11 Wafers ------- 2-8

2-4. Solar P-V Energy Research, Development and Demonstration Act of 1978, (Pubiic Law 95-590)

Forecast for Flat Plate Solar Cell Arrays ------------ 2-8

2-5. Medium Forecast for Flat Plate Solar Cell Array

Delivery

2-9

2-6. Low Forecast for Flat Plate Solar Cell Array

Delivery

$2-9$

3-1. Polycrystalline Silicon: Free World Existing and Planned Plant Capacity (in Metric Tons) --_---_---- 3-1

3-2. Free World Existing Plant Capacity for Single Crystal Silicon Ingots and Wafers --------_------------ 3-6

3-3. Installed and Operating Crystal Single Ingot Growth Systems of Major U.S. Producers --

4-1. Polycrystalline Silicon (Without Solar): Comparison of Capacity and Market Needs (in Metric Tons) -------- 4-1

4-2. Polycrystalline Silicon Solar Capacity and Market

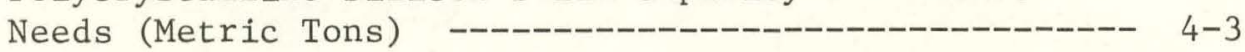

4-3. Polycrystalline Silicon (Solar and Non-Solar): Comparison of Capacity and Market Needs for High Forecast (Metric Tons)

4-3a. Polycrystalline Silicon (Solar and Non-Solar): Comparison of Capacity and Market Needs for Median Forecast (Metric Tons) 
4-3b Polycrystalline Silicon (Solar and Non-Solar): Comparison of Capacity and Market Needs

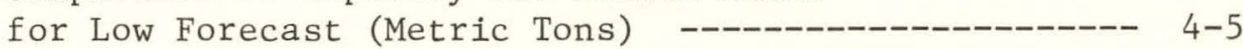

4-4. Single Crystal Silicon: Comparison of Capacity and

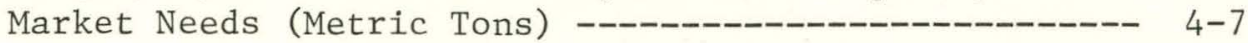

4-5. Silicon Wafers: Comparison of Market and Capacity $\left(10^{6} \mathrm{~m}^{2}\right)$-- 


\section{EXECUTIVE SUMMARY}

\section{Synopsis}

Photovoltaic solar cell arrays which convert solar energy into electrical energy can become a cost-effective, alternative energy source provided that an adequate supply of low priced materials and automated fabrication techniques are available.

Presently, the photovoltaic industry is dependent upon polycrystalline silicon which is produced primarily for integrated circuits, power devices, and the discrete semiconductor device industry. This is expected to be the only significant source of supply until DOE-sponsored new technology polysilicon becomes available and the photovoltaic industry develops its own source of supply. Recent industry forecasts have predicted a limited supply of polycrystalline silicon material and a shortage could occur in the early $80^{\prime}$ 's from increasing demands by the semiconductor integrated circuit and power device manufacturers. Implementation of the Solar Photovoltaic Energy Research, Development and

- Demonstration Act of 1978 (Public Law 95-590) dated November 4, 1978 will be affected by the forecast.shortage.

In response to these concerns, The Jet Propulsion Laboratory's Technology Development and Application Lead Center formed an ad hoc committee of JPL, SERI and consultant personne1. The committee was to review the availability of silicon material, single crystal ingot growing, and wafer slicing capabilities to meet the manufacturing needs of the photovoltaic industry during 1980-1985. It conducted interviews with key polycrystalline manufacturers and a large cross-section of single crystal ingot growers, wafer manufacturers, silicon material equipment manufacturers, integrated circult manufacturers and silicon solar cell manufacturers.

Industry consensus and conclusions reached from the analysis of the data obtained by the committee are summarized below:

- There is a high probability of polycrystalline silicon shortage by the end of CY 1982 and a strong seller's market after CY 1981 which will foster price competition for available silicon because of :

(1) The persistence of strong market demands by the integrated circuits industry.

(2) Any recession in the 1979-1980 period is not expected to have significant effect on demand based on previous recessions.

(3) Expansion of Siemens-process manufacturing capacity with new plants which has occurred in the past to meet market demands is now unlikely. Industry is convinced that:

(a) DOE-sponsored, low-cost processes are becoming commercially ready 
(b) Polycrystalline silicon price from new Siemens plants is expected to be in excess of $\$ 100$ to compensate for investment.

- Some capacity expansion of existing plants is possible (up to $20 \%$ expansion at a moderate increase in price). This will only delay the projected shortage by a few months.

- DOE-sponsored (LSA Project) new polycrystalline silicon production processes have been proven technically feasible and, per present DOE plans, large-scale plants can be operational by 1986 .

- The single crystal ingot growing and wafer slicing plant capacity is and will remain in balance with the needs of its users.

- Advanced thin-film based photovoltaic cell processes will probably not be commercially ready before 1985 .

- Unless the polycrystalline industry spearheads new production techniques and processes to increase its capacity within the next 12 months, implementation of Public Law 95-590 will require government involvement in sponsoring the expansion of the poly-. crystalline silicon production capacity. Industry has stated that long-range procurement contracts will be needed before it will be willing to invest on its own.

This report is limited to the extent that proprietary information retained by the industry could modify the conclusions. Technological developments could take place, thereby substantially improving the potential for industry to develop the needed production capacity and to achieve the economic goals of the photovoltaic silicon array industry. Many plans which are proprietary within each affected company could impact the future silicon availability; but, for the present, it is necessary that any procurement planning consider the potential of a silicon shortfall in 1983 and the period beyond.

\section{Introduction}

The use of photovoltaic arrays to generate electrical energy for the nation's energy needs depends upon large quantity availability of low cost materials. Since polycrystalline silicon is presently the prime candidate material for these solar cell arrays, the array market price will depend in part on the price of this material. The Solar Photovoltaics Energy Research, Development and Demonstration Act of 1978

- (Public Law 95-590) dated November 4, 1978, requires the polycrystalline silicon industry to supply polycrystalline silicon in ever increasing quantities to achieve an annual production rate of 500 megawatts of peak array power by 1986 . Twenty metric tons of polycrystalline silicon was required to manufacture solar cells capable of generating the one megawatt of peak power produced during 1978. Between 2500 and 3000 metric tons of polycrystalline silicon will be required to manufacture.the solar cells necessary to generate the 250 megawatts of peak power forecast for 1985; an anticipated utilization of between 10 and 12 metric tons per megawatt. 
Recent industry forecasts have predicted a limited supply of polycrystalline silicon material and a shortage could occur in the early 80 's from increasing demands by the semiconductor integrated circuit and power device manufacturers. If a polycrystalline silicon material shortage does occur, it could have a limiting effect on the growth of the terrestrial photovoltaic industry.

The Jet Propulsion Laboratory's Technology Development and Application Lead Center, in early June 1979, formed an ad hoc committee of JPL, SERI and consultant personnel. The committee was to review the availability of silicon material, single crystal ingot growing, and wafer slicing capabilities to meet the manufacturing needs of the solar cell industry during 1980-1985. The information obtained in these interviews and its analysis are summarized in this report.

\section{Industry Survey}

Members of the ad hoc committee visited, telephoned, and sent questionnaires to key polycrystalline silicon manufacturers, and a large crosssection of single crystal ingot growers, wafer manufacturers, silicon material equipment manufacturers, integrated circuits manufacturers and silicon solar cell manufacturers. The principal manufacturers and other sources that provided inputs to this report are:

- Hemlock Semiconductors
- Wacker Chemical
- Texiel Silicon Products
- Great Western
- Motorola
- Silicon Technology
- Alectronic News
- Applied Solar Energy

\author{
- Solar Power \\ - Varian/Lexington Vacuum Division \\ - P. R. Hoffman \\ - Sawyer Research Products \\ - ARCO Solar \\ - Siltec \\ - Leybold-Heraeus \\ - Fluoroware \\ - Solarex
}

\section{Highlights}

A major polycrystalline silicon material manufacturing industry has grown to meet the needs of integrated circuits and discrete semiconductor device manufacturers. The industry has aggressively increased its capacity and its productivity every year since its inception in 1953 to serve the demands shown in Figure 1. During 1978, the free world industry produced over 2400 metric tons of polycrystalline silicon. Of the silicon produced, $85 \%$ is acceptable for use by the integrated circuit and power device manufacturers. The $15 \%$ of rejected material is either reprocessed or purchased by the photovoltaic industry for production of solar ceilis. Data obtained during the industry interviews on the present and projected polycrystalline capacity from existing plants is shown in Table 1.

'l'he continuing growth of the integrated circuits business in 1977-1979, and into the foreseeable future is now taxing the polycrystalline sources. A concern has developed that polycrystalline silicon could suon be in 


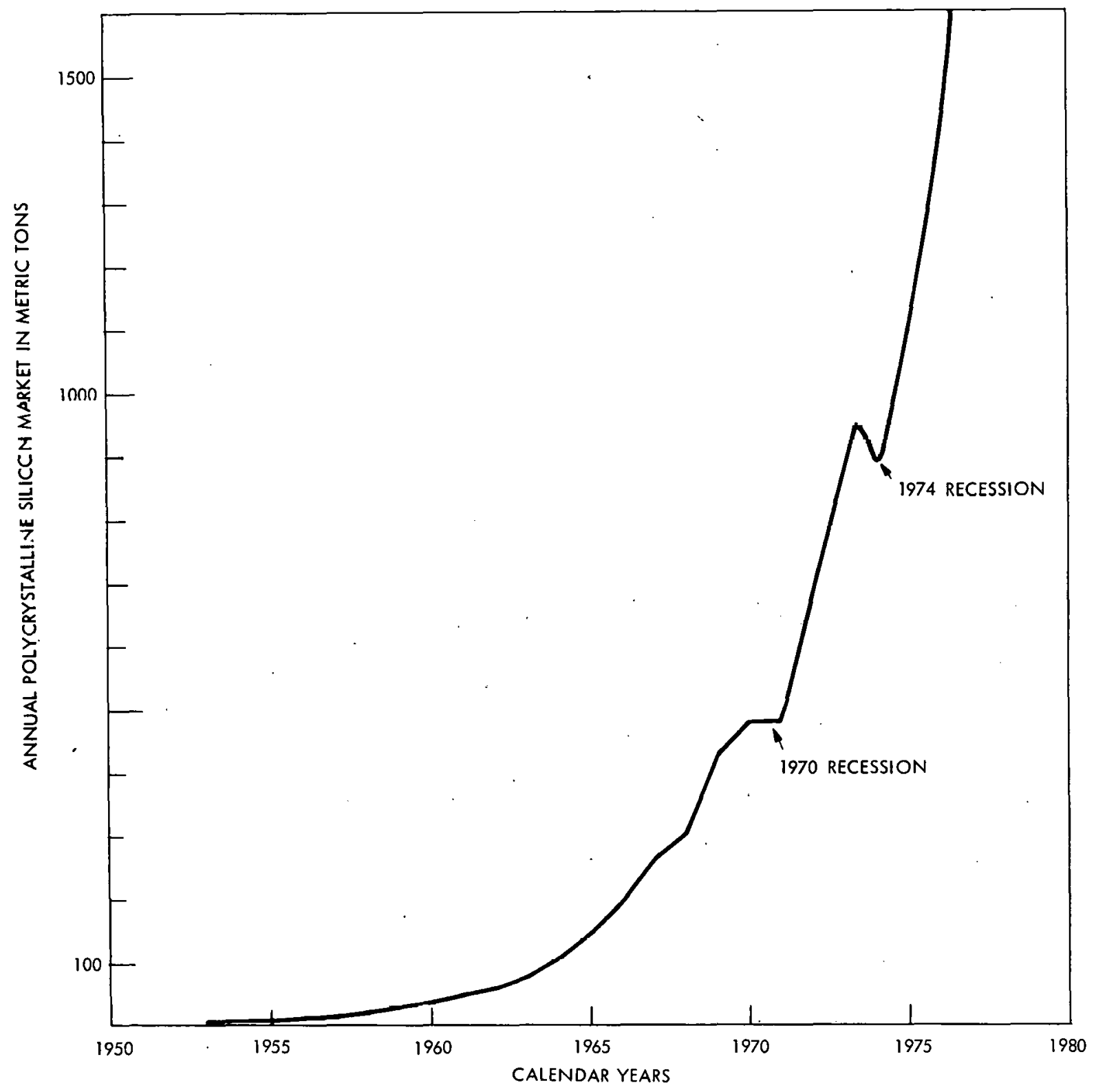

Figure 1. Polysilicon Material Demand Versus Calendar Years

limited supply to meet the integrated circuits needs. Snme increase in existing plant capacity $(\sim 20 \%)$ is possible at potentially higher prices.

The polycrystalline industry consensus was that: (a) the integrated circuits and power device manufacturers are now experiencing delays in receiving polycrystalline silicon; (b) there will be limited availability of polycrystalline silicon at the end of CY 1981; and (c) a net shortage of polycrystalline silicon could materialize by the end of CY 1982 with the integrated circuit and power device manufacturers then bidding for reprocessed material which has been used for the photovoltafc market as shown in Figure 2. Figure 2 shows the current and projected polycrystalline supply and demand for non-solar and solar industry. For the solar ,demand, three forecast scenarios have been used. 
Table 1. Polycrystalline Silicon: Free World Existing Plant Capacity (In Metric Tons)

\begin{tabular}{|c|c|c|c|c|c|c|c|c|c|}
\hline Plant & 1977 & 1978 & 1979 & 1980 & 1981 & 1982 & 1983 & 1984 & 1985 \\
\hline Wacker (Germany) & 700 & 700 & 700 & 800 & 850 & 875 & 875 & 875 & 875 \\
\hline Dow Corning & 500 & 500 & 500 & 700 & 775 & 850 & 900 & 950 & 1000 \\
\hline Texas Instruments & 175 & 175 & 200 & 250 & 275 & 300 & 325 & 325 & 325 \\
\hline Monsanto & 175 & 190 & 200 & 210 & 220 & 230 & 230 & 230 & 230 \\
\hline Smiel (Italy) & 150 & 175 & 190 & 200 & 210 & 220 & 230 & $230^{\circ}$ & 230 \\
\hline Motorola & 100 & 100 & 100 & 100 & 100 & 100 & 100 & 100 & 100 \\
\hline Topsil (Denmark) & 15 & 15 & 20 & 25 & 25 & 25 & 25 & 25 & 25 \\
\hline Siemens (Germany) & 10 & 10 & 10 & 10 & 10 & 10 & 10 & 10 & 10 \\
\hline Great Western & - & 10 & 50 & 100 & 120 & 140 & 150 & 150 & 150 \\
\hline Japan & 280 & 254 & 300 & 300 & 300 & 300 & 300 & 300 & 300 \\
\hline $\begin{array}{l}\text { Total Acceptable } \\
\text { Capacity for Inte- } \\
\text { grated Circuits } \\
\text { and Power Devices } \\
\text { Not Including Re- } \\
\text { processed Material }\end{array}$ & 2105 & 2129 & 2270 & 2695 & 2885 & 3050 & 3145 & 3195 & 3245 \\
\hline
\end{tabular}

Reasons for the forecast polycrystalline silicon shortage can be summarized as follows:

1. The growth of the integrated circuits industry has caused a doubling of silicon usage during 1977-1979, and high growth is forecast to continue.

2. Any recession in the 1979-1980 time period is not expected to have a significant effect upon the long-term demand for polycrystalline silicon. Overall growth continued during 1970 and 1974 recession periods. See Figure 1.

3. It is highly unlikely that the industry will invest in new silicon production plants which are based on the presently used 


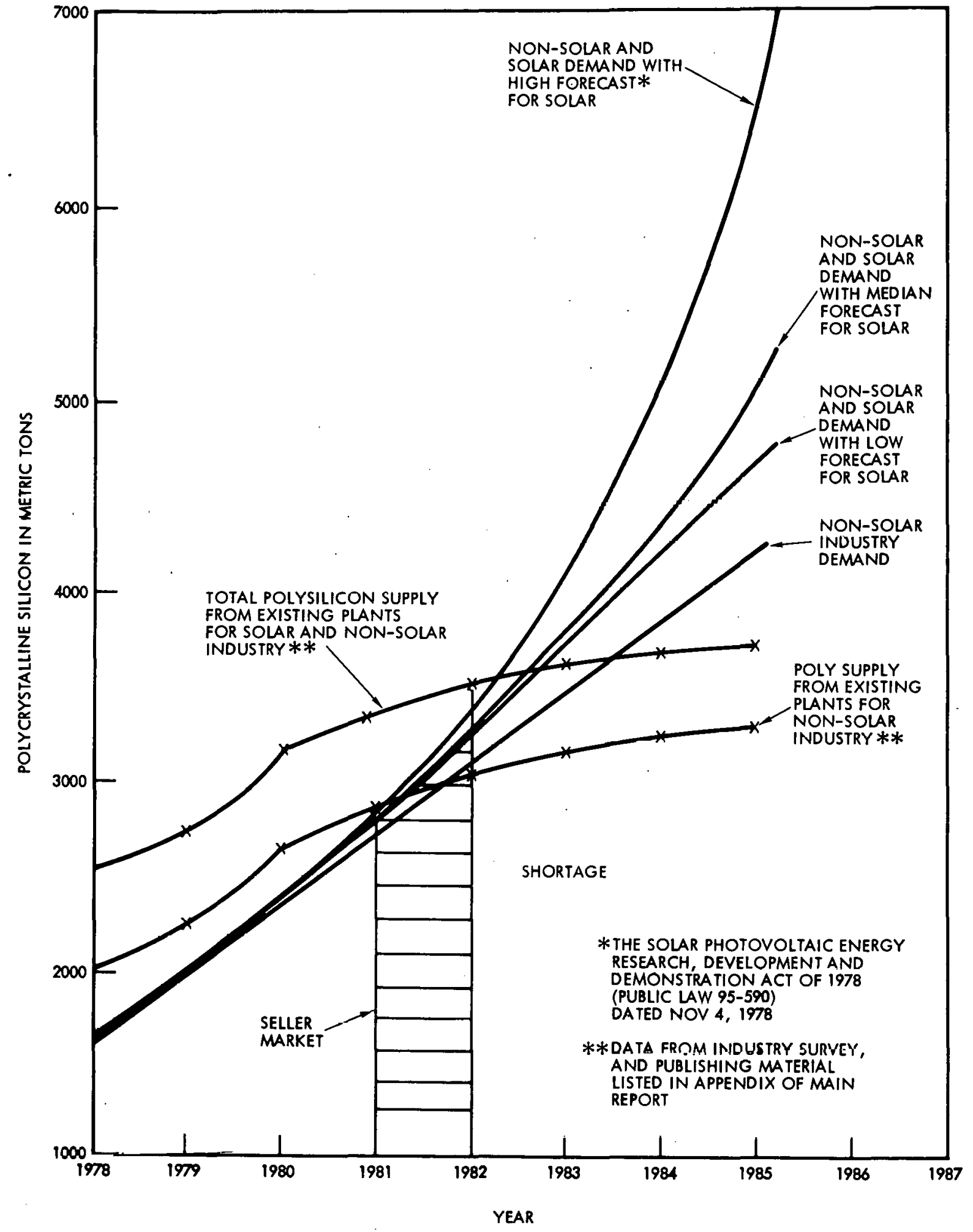

Figure 2. Current and Projected Polycrystal Material Supply and Demand Requirements 
Siemens-process. The main arguments against such new installations are: (a) The total product cost of silicon from new Siemens-process plants would be significantly greater than from existing plants (which were installed in the 1967. to 1974 period and are mostly depreciated). Higher costs would probably necessitate commensurately higher prices to allow for an acceptable profit and a reasonable write-off time. That adequately high prices will occur at the appropriate times to make Investments in new plants commercially feasible is too uncertain to encourage plans for these installations. (b) Progress has been made in the Low Cost Solar Array Project (under DOE. contract to JPL) in developing new processes to produce low cost, semiconductor grade silicon. There is a high probability that the 1986 price goal ( $\$ 14 / \mathrm{kg}$ compared to about $\$ 65 / \mathrm{kg}$ in $\$ 1980$ ) will be achieved by one or more of these processes. Hence, the likelihood that a new process will be used in silicon production plants about 1986 leads to a reluctance to invest in Siemens-process new plants.

The solar cell industry will require substantial amounts of polycrystalline silicon for development efforts and demonstration projects from 1980 to 1985. This silicon will have to be obtained from the same producers that supply the integrated circuits industry unless other capacity is installed somehow to provide silicon for the solar cell industry only.

Discussions with industry revealed a lack of confidence in government procurement planning. Industry prefers staggered orders and long-range, firm procurement contracts with guaranteed government involvement before they would be willing to invest on their own to the degree necessary to meet the requirements of Public Law 95-590.

The interviews also revealed that the semiconductor device industry and the developing photovoltaic industry prefer to use the vertical integration approach to be competitive for future business and to remove materials supply uncertainty.

The single crystal growing and wafer slicing industry interviews showed that the industry plant capacity is in balance with the need for the integrated circuits and power device industries. This capability will continue to expand and will remain in balance with need. The acquisition lead time necessary for crystal growers and slicers is relatively short at one year. Thus, capacity can be installed as needed.

A11 industry representatives agree that in 1980-85, most of the advanced photovoltaic materials and processes (silicon and nonsilicon $\sum$ sponsored by DOE will not likely be ready for commercial application. However, technology developments may occur, and new technology processes, spearheaded by industry, for producing low cost, semiconductor grade polycrystalline silicon may be installed in this time period. 


\section{Conclusions}

Committee conclusions from the industry inverviews and analysis of the data obtained are:

- There is high probability that a shortage of semiconductor grade polycrystalline silicon will occur by the end of CY 1982. The reasons given for this forecast are summarized as follows:

1. Undiminished growth of the integrated circuits industry caused stlicon use to double from 1977 to 19.79, and high growth is forecast to continue.

2. No significant effect on the 1ong-term demand for semiconductorgrade silicon is expected from an economic recession which may take place in the 1979 to 1980 period. This conclusion was based on a history of the effects of previous recessions on polycrystalline silicon demand.

3. It is highly unlikely that the industry will invest in new silicon production plants which are based on the presently used Siemens-process. The main arguments against such new installations are: (a) The total product cost of silicon from new Siemens-process plants would be significantly greater than from existing plants (which were installed in the 1967 to 1974 period and are mostly depreciated). Higher costs would probably necessitate commensurately higher prices to allow for an acceptable profit and a reasonable write-off time. That adequately high prices will occur at the appropriate times to make investments in new plants commercially feasible is too uncertain to encourage plans for these installations. (b) Progress has been made in developing new processes to produce low cost, semiconductor-grade silicon. Hence, the likelihood that a new process will be used in silicon production plants about 1986 leads to a reluctance to invest in Siemens-process new plants.

- Persistence of present market conditions will result in a strong sellers market by the end of CY 1981. The price of polycrystalline silicon will remain determined by competition within the semiconductor devices industry.

- Some capacity expansion of existing plants is possible (up to $20 \%$ expansion at moderate increase In price). Th1s w111 only delay the projected polycrystalline silicon material shortage by a few months.

- The silicon requirements to meet PV demand called for in The Solar Photovoltaic Energy Research, Development and Demonstration Act (Public Law 95-590) dated November 4, 1978 would necessitate polycrystalline silicon in rapidly increasing quantities. The quantities of polycrystalline silicon required to support the production growth for two advanced solar cell fabrication approaches against the anticipated available supply are shown in Figure 3. 


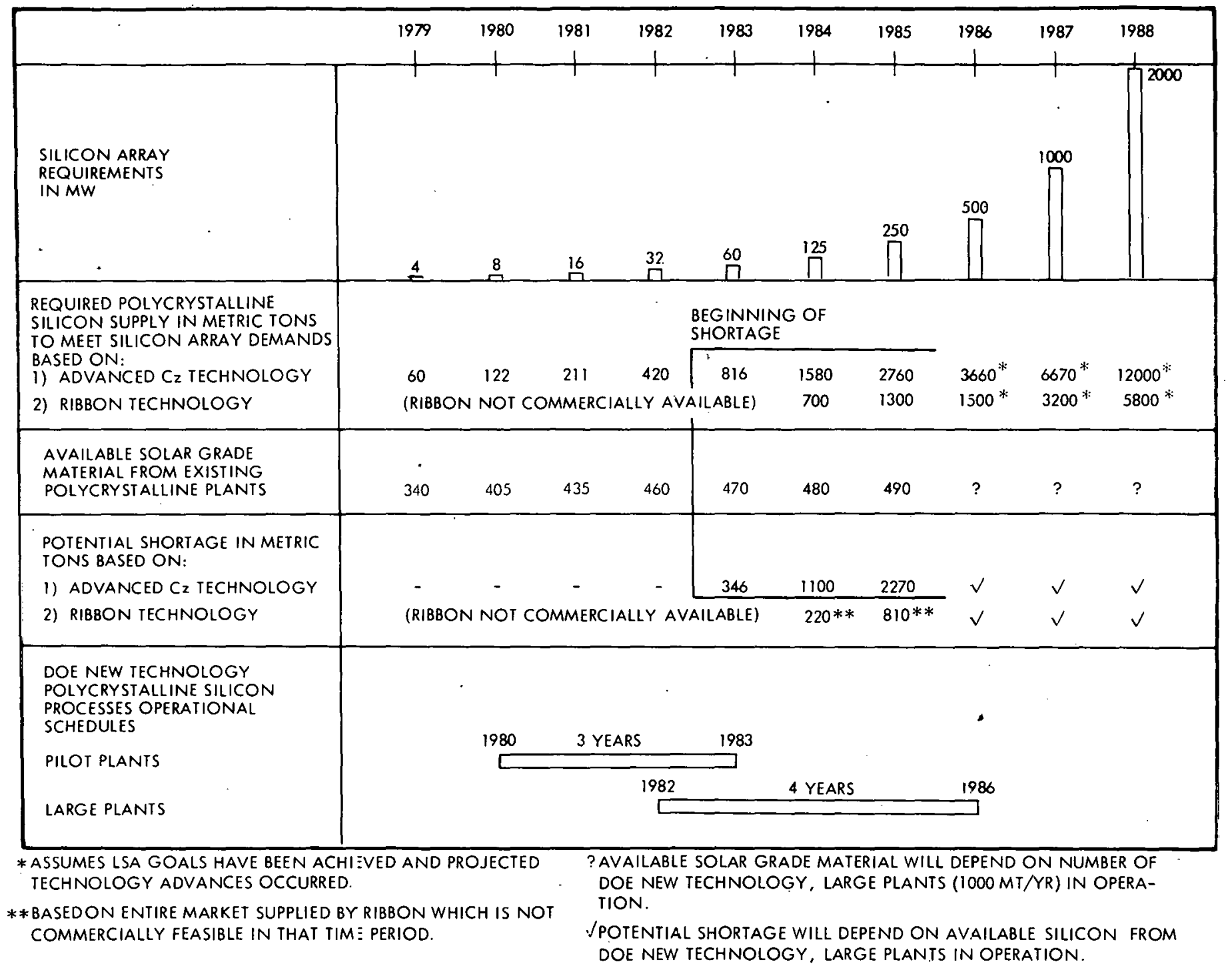

Figure 3. Silicon Supply Scenario for the Solar Photovoltaic Energy Research Development and Demonstraticn Act of 1978 (Public Law 95-590) dated November 4, 1978 
- Advanced thin-film based photovoltaic cell processes will not likely be ready for commercial application in the time period of interest to this study. Thus, the photovoltaic materials demand projections herein are based primarily on single and/or cast polycrystalline silicon solar cell technologies.

- New technologies, developed under the Low Cost Solar Array Project, to produce low cost polycrystalline silicon will not result in commercial capacity before 1986 under the present schedule shown in Figure 3.

- Single crystal ingot growing and wafer slicing plant capacity is in balance with the needs of the users, and this capacity will continue to expand. The acquisition lead time necessary for crystal growers and wafer slicers is relatively short at one year, so that no photovoltaic programmatic actions are necessary to increase volume capability. The present LSA process improvement work will be used in industry as each new technology item becomes fully demonstrated (such as multi-blade saws).

- The developing photovullaic industry and the semiconductor device industry prefer to use the vertical integration approach to remove materials supply uncertainty.

Conditions which could modify the projected shortfall in polycrystalline silicon supply would include a more rapid advance than is presently envisioned in ribbon growth technology. This would reduce the quantity of polycrystalline silicon consumed in ingot growing and slicing processes. Sillcon device manufacturers could add additional polycrystalline capacity to their present capability to assure sufficient materials for their own device needs. This could release some polysilfcon from present supply sources for solar cell manufacturing. Also, polycrystaline silicon suppliers may elect to expand their existing facilities through process modifications. Other polycrystalline users may decide to begin manufacturing their own material for assured supply and potential cost advantages. Many plans which are proprietary within each affected company could impact future silicon availability; but, for the present, it is necessary that any procurement planning consider the potential of a silicon shortfall in 1983 and beyond.

The consensus was that growth of the solar photovoltaic industry as a potential supplier of appreciable amounts of the nation's electrical power depends upon substantial progress during 1980 to 1985 in technology development and transfer and in the early inatilliation of photon voltaic systems. The majority of government-funded demonstration projects are likely to be built during this period. The common need is for the availability of a sufficient quantity of polycrystalline silicon at a low price. The consensus was that meeting this need was absolutely required to create the appropriate economic conditions for a solar photovoltaic industry to develop. 


\section{SECTION I}

INTRODUCTION

\section{A. OBJECTIVE}

The acceptability of photovoltaic solar arrays as an alternate energy source depends upon its price competitiveness with other energy sources. Since the basic material used in the manufacture of solar arrays is silicon, its cost must be low, its quality high, and its availability assured.

Early in 1979, industry concerns began to circulate ( 1 ) that the growth of the integrated circuits business from 1977-1979 was forcing polycrystalline silicon plants to produce at capacity. It was further projected that polycrystalline silicon could soon be in limited supply for integrated circuits and power devices, and could be in critical supply to the developing solar cell industry.

In response to these concerns, the Jet Propulsion Laboratory's Photovoltaic Technology Development and Applications Lead Center in early June 1979 formed an ad hoc committee of JPL, SERI and consultant personnel. The committee was to determine the availability of silicon materials for the manufacture of solar cells during 1980-1985. It conducted industry interviews per procedures outlined in Appendix A.

Members of the committee visited, telephoned, and sent questionnaires to key polycrystalline silicon manufacturers, and a large cross-section of single crystal ingot growers, wafer manufacturers, silicon material equipment manufacturers, integrated circuits manufacturers and silicon solar cell manufacturers. The manufacturers and other sources that provided inputs to this report are:

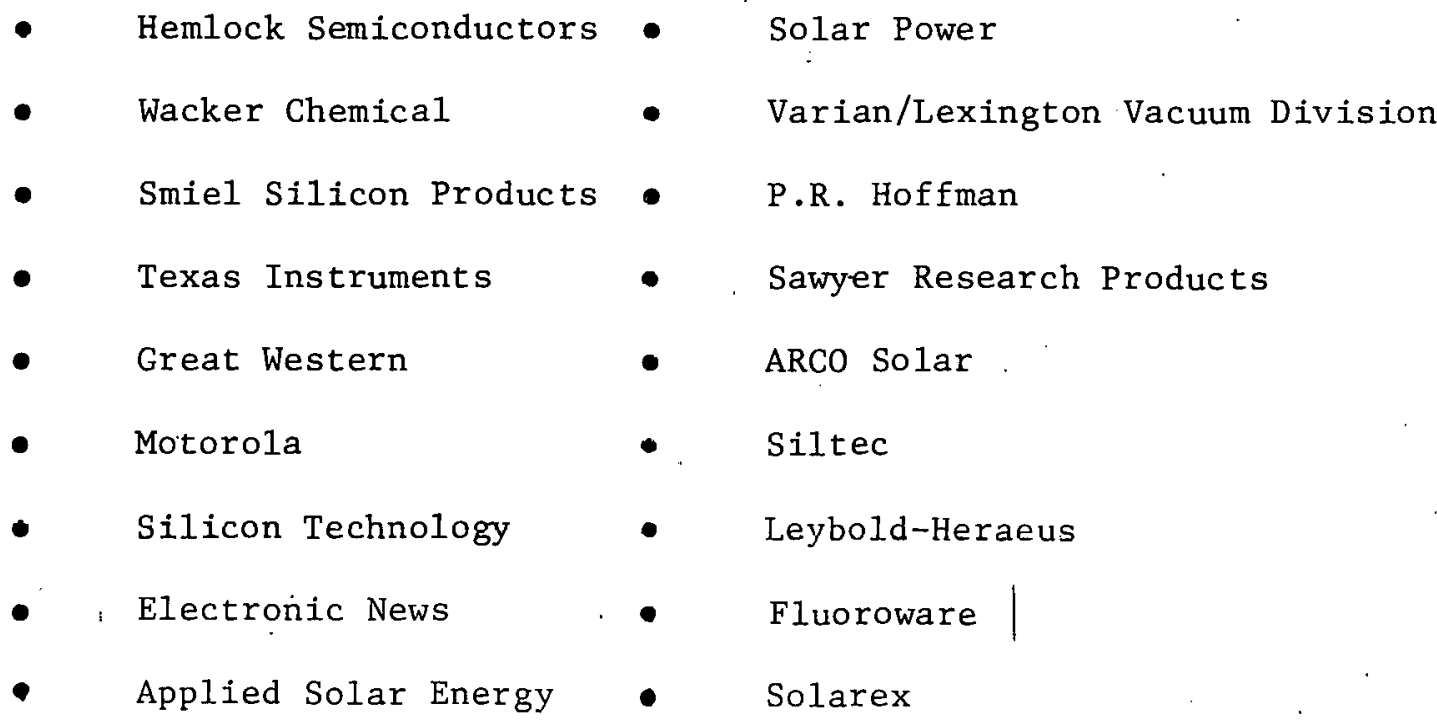




\section{B. BACKGROUND}

The silicon materials industry has grown to meet the needs of the integrated circuit and discrete semiconductor device manufacturers. This industry has aggressively increased its capacity and productivity every year since its inception in 1953. The semiconductor device annual market for polycrystalline silicon, single crystal ingot and wafers is shown in Figures 1-1, 1-2 and 1-3. In 1978, the free world manufactured $3.43 \times 10^{9} \mathrm{~cm}^{2}\left(0.343 \mathrm{~km}^{2}\right)$ of single crystal silicon wafers and about 2400 metric tons of polycrystalline silicon.

The industry is worldwide in scope with major plants in the United States, Europe, Japan and Malaysia. The United States is a net importer from all manufacturing areas. While many semiconductor device manufacturers produce their own silicon, a commercial market also exists. The commercial market for semiconductor silicon has become increasingly dominant.

'I'he silicon materials 1ndustry hegan in 1952 when Bc11 Telephunte Laboratory asked DuPont Company to manufacturc 1000 pounds of hyper-pure elemental silicon to use in developing transistors, various diodes and solar cells.

In 1953, Siemens in Germany initiated a research program to develop a manufacturing process.for polycrystalline silicon. The Siemens process, with evolutionary improvements, is used today to manufacture most of the polycrystalline silicon.

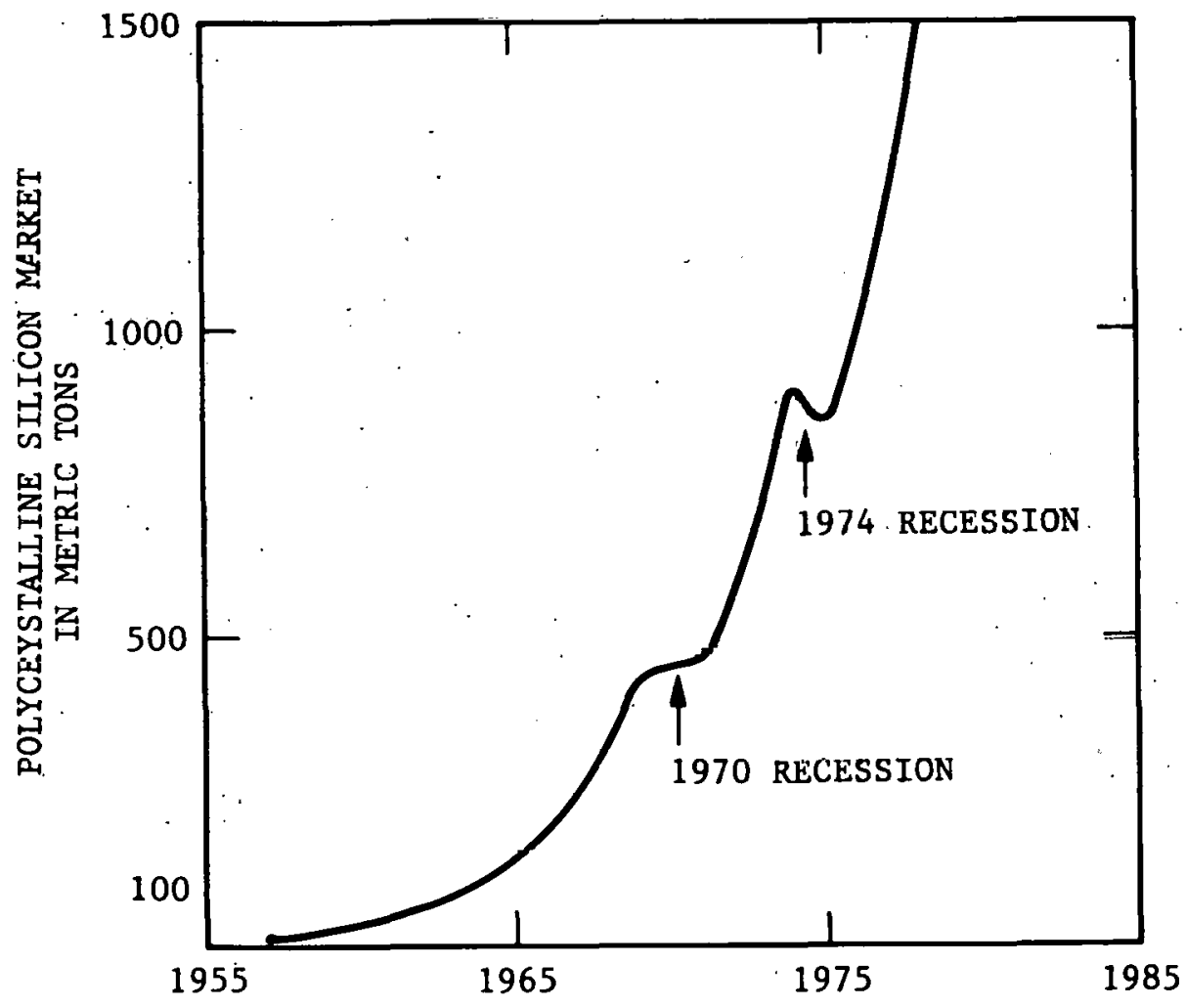

Figure 1-1. Polycrystalline Silicon Market Over Calendar Years 


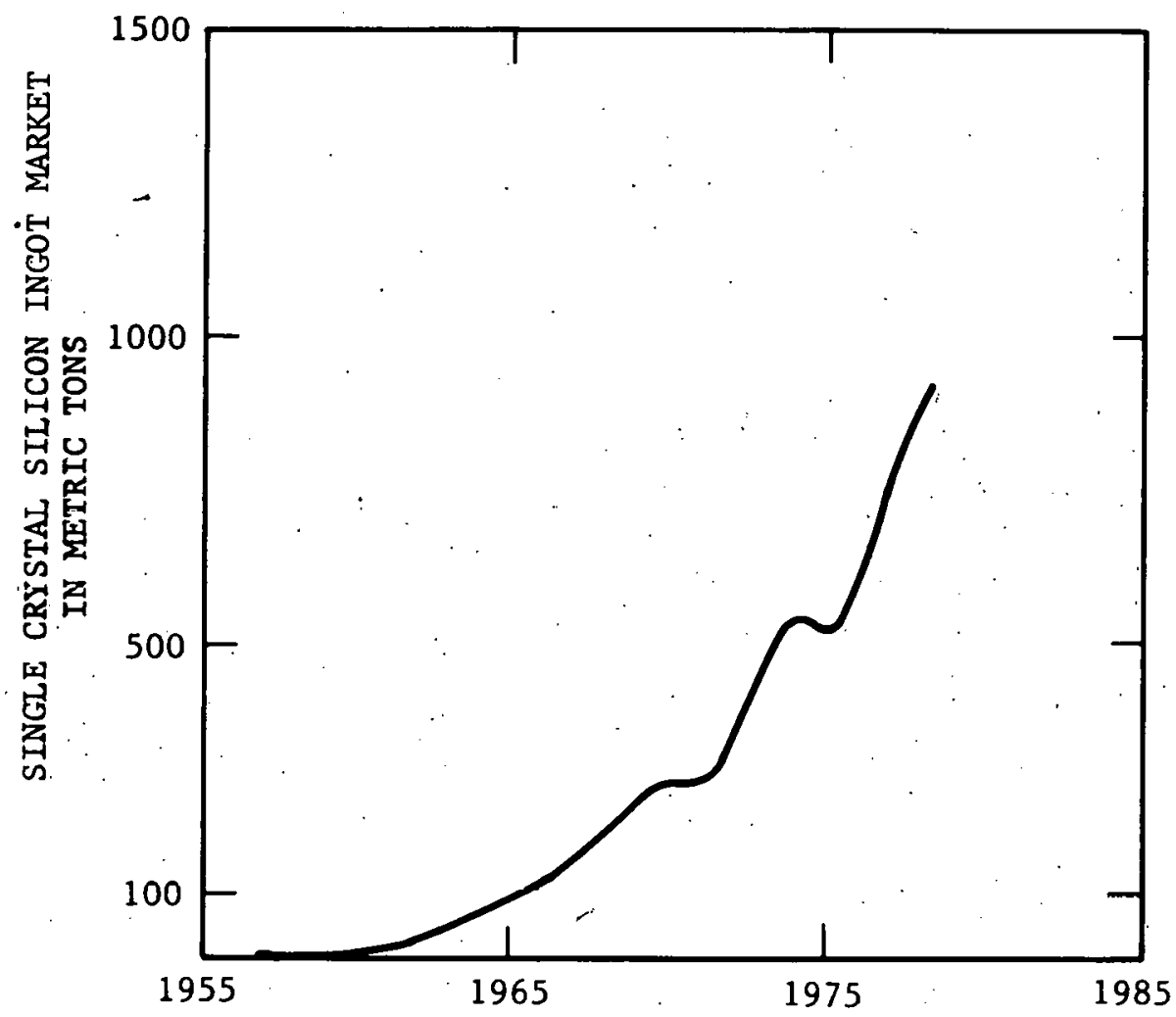

Figure 1-2. Single Crystal Silicon Ingot Market Over Calendar Years

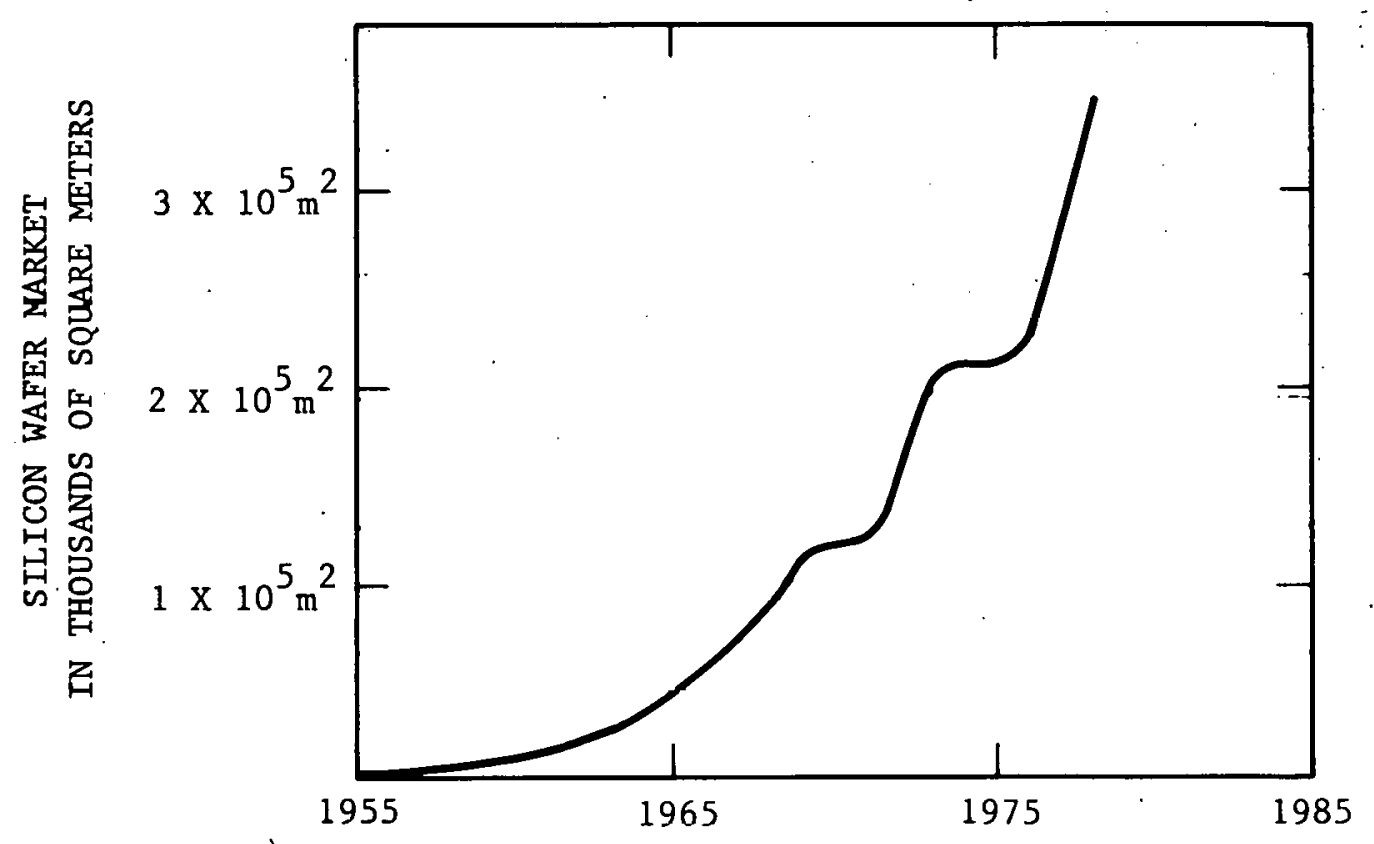

Figure 1-3. Silicon Wafer Market Over Calendar Years 
By 1962 , the total annual world market for silicon wafers was $\$ 34,000.000$. The price of polycrystalline silicon was over $\$ 100 / \mathrm{kg}$ and : the price of single crystal ingot averaged $\$ 600 / \mathrm{kg}$. There were at least twelve commercial companies in the polycrystalline silicon business, and at least 30 semiconductor device companies internally manufacturing silicon materials. Several commercial companies including DuPont, Union Carbide, Mallinckrodt, Transitron and Merck discontinued their market participation. This left the following companies to supply the demand on a commercial basis.

(1) (Dow Corning) Hemlock

(2) Monsanto

(3) Montecatini (Montedison, now Smiel)

(4) Shinetzi Handotai

(5) Wacker Chemical

(6) Texas Instruments

These companies are still the major suppliers of polycrystalline silicon materials. Most semiconductor device manufacturers having some materials supply have tended to grow and slice crystal ingot, not manufacture polycrystalline silicon. Semiconductor device companies with important polycrystalline silicon materials, ingot growing and slicing capabilities are:

(1) Fairchild Semiconductor

(2) General Motors

(3) IBM

(4) Motorola

(5) Texas Instruments

(6) Western Electric 


\section{SECTION II}

\section{MARKET FORECAST FOR POLYCRYSTALLINE \\ SILICON AND SILICON WAFERS}

\section{A. INTRODUCTION}

Presently, almost 1000 companies manufacture tens of thousands of silicon devices. A number of forecasts are available of the quantity of such devices to be manufactured each year. Forecasts are made annually by Electronics (McGraw-Hí11) In January (10), and Semiconductor Information Services, a division of Semi Inc. (11). From such estimates, the. annual requirements for polycrystalline silicon, single crystal ingots and wafers can be accurately calcullated.

In this forecast, the silicon material requirements are divided into three categories.

(1) Integrated circuits and silicon devices requiring polished wafers.

(2) Power devices and discrete components not requiring polished wafers such as rectifiers and thyristors.

(3) Silicon solar cells, an industry so new that prediction is difficult. In this report, the requirements used are based on the Solar Photovoltaic Energy Research, Development and Demonstration Act of 1978 (Public Law 95-590) dated

Nov. 4, 1978 and on two less aggressive market scenarios.

\section{B. INTEGRATED CIRCUITS}

The number of square centimeters of polished silicon wafers used in 1977 and 1978 and a forecast for 1979 - 1985 is provided for integrated circuits in Figure 2-1. This prediction is based on general industry trends and data obtained from the industry survey. (12-15) 


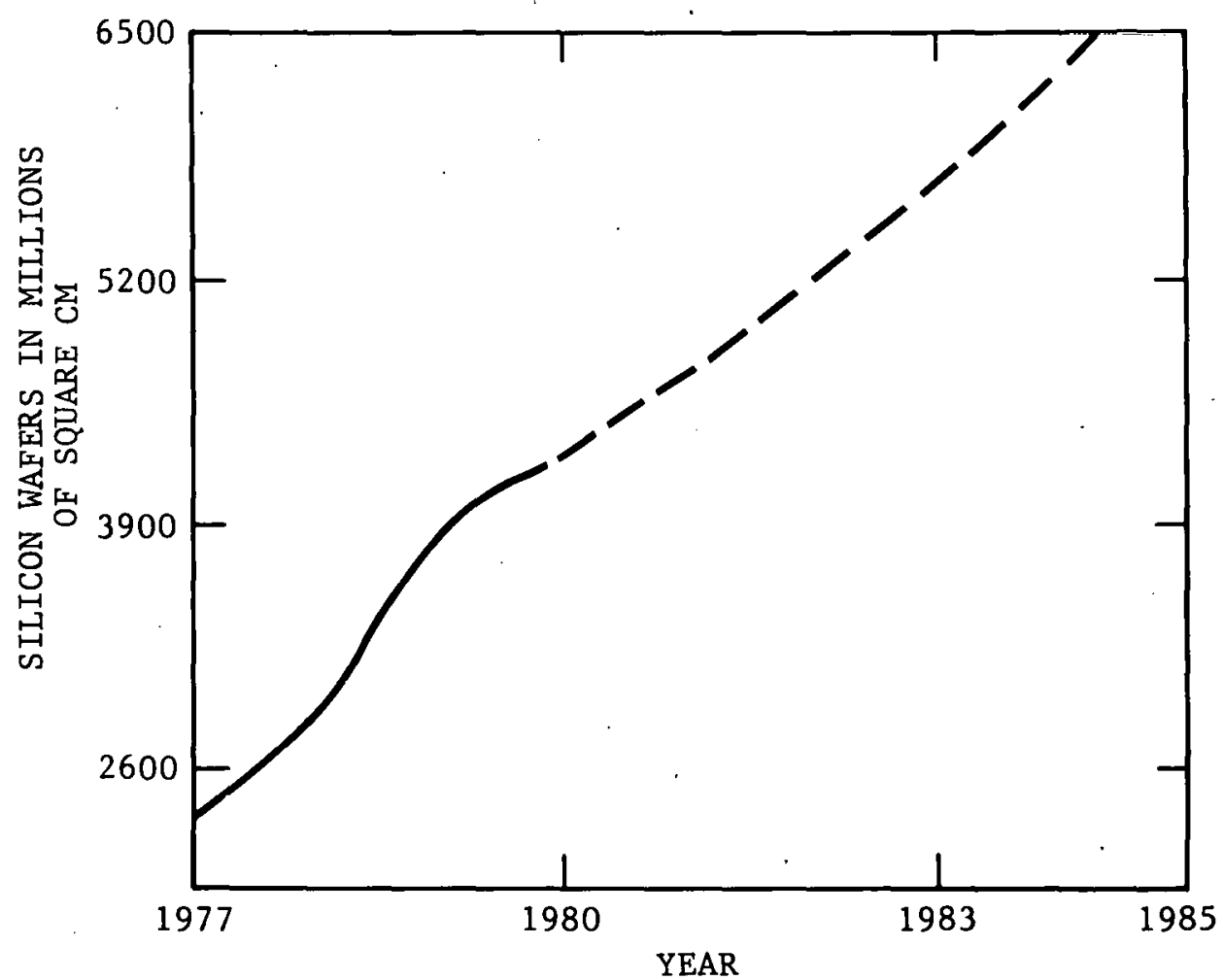

Figure 2-1. Free World Market Forecast to 1985 of Polished Silicon Slices for Inlegrated Circuils

In general, nine significant process steps are required to transform polycrystalline silicon into wafers for integrated circuits application. Each step results in some material loss. The significant loss occurs in the growth of polycrystalline silicon into single-crystal i. ingoto. Other process oteps which olice the ingot into wafcro and finish the wafers into polished slices also result in loss of silicon. The amount of silicon required for the wafers, including the losses are illustrated in Table 2-1.

Table 2-1. Polycrystalline Silicon Requirement Per Polished S1ice

(Integrated Circuits)

\begin{tabular}{ccc}
\hline Dlamelel of Wafer & Singlc Cryotal Wafer & Polyerystalline Si1irnn \\
\hline $7.5 \mathrm{~cm}$ & 1.86 gram & 2.92 grams \\
$10.0 \mathrm{~cm}$ & 2.08 grams & 3.27 grams \\
$12.5 \mathrm{~cm}$ & 2.38 grams & 3.74 grams
\end{tabular}

Based on the data of Table 2-1, Figure 2-2 shows the actual demand and forecasts the market need for polycrystalline silicon and single crystal ingot for the integrated circuits industry from 1979 - 1985. 


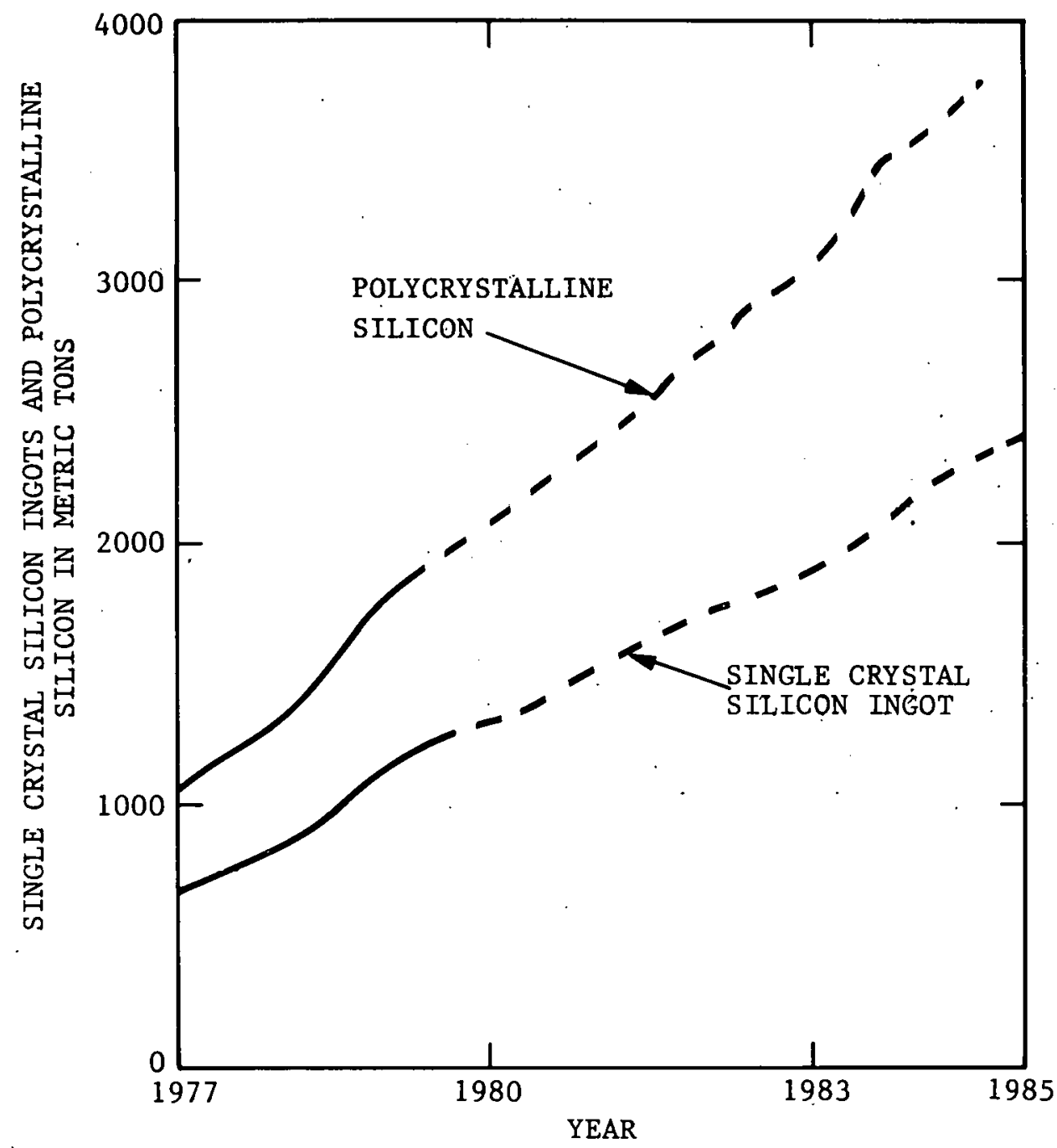

Figure 2-2. Free World Market Forecast to 1985 of Single Crystal Silicon Ingots and Polycrystalline Silicon for Integrated Circuits 


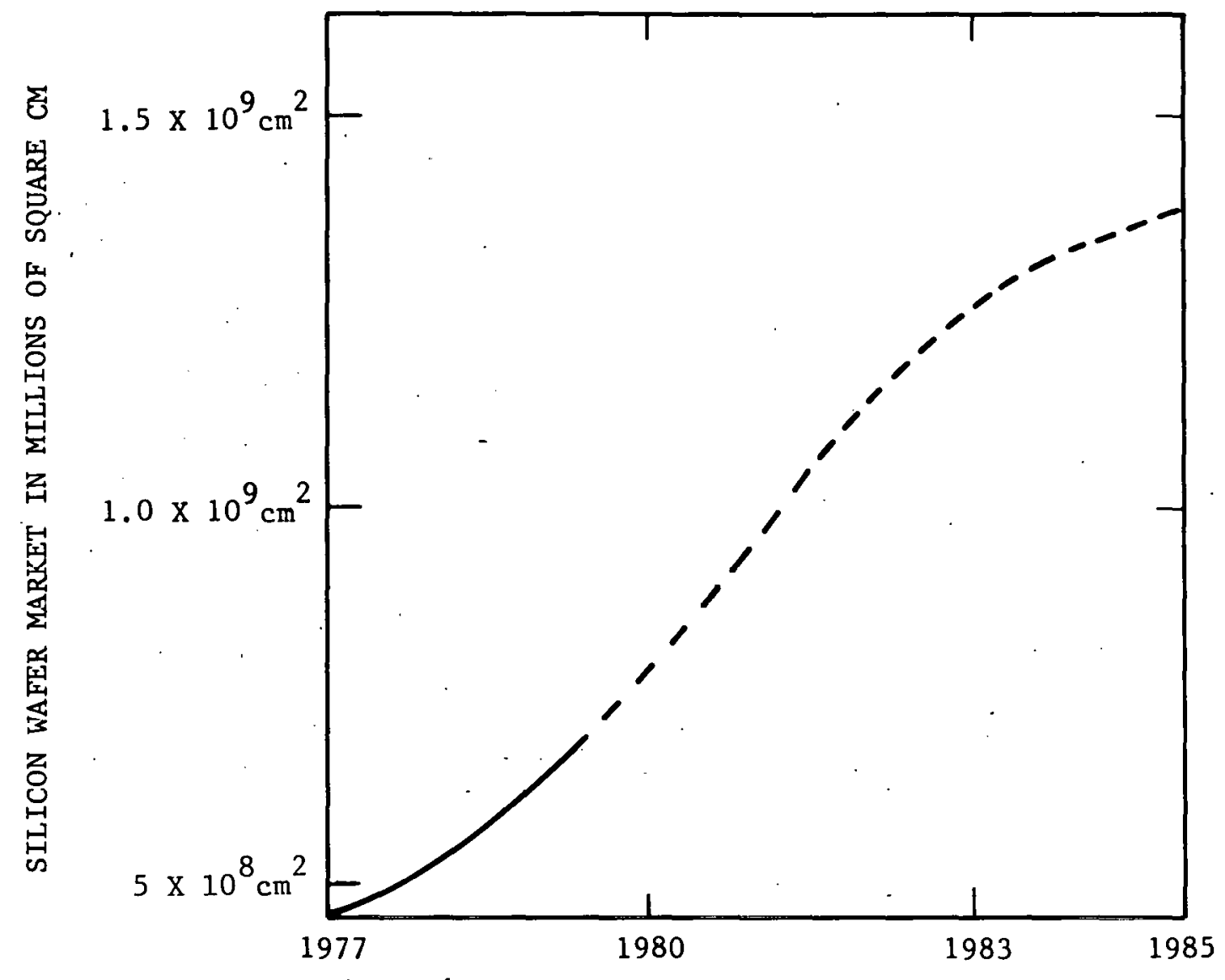

Figure 2-3. Free World Market Forecast to 1985 of Silicon Waters for Tower Devices

\section{POWER DEVICES}

This group of semiconductor devices includes all power devices such as thyristors, rectifiers, VMOS and bipolar power transistors. It also includes all discrete components that do not require the use of polished silicon slices. This segment of the semiconductor device industry was expected to level-off in growth. The leveling-off did not occur for a number of reasons. The increased cost of electrical power has made the use of new semiconductor motor controls (16) and electric light controls practical (17). Microprocessor controls have made valve actuators necessary (18). Increased gasoline costs have made new automotive controls a necessity. (19).

The number of square centimeters of silicon wafers used in 1977 through 1978 and a forecast for use in 1979'through 1985 is provided in Figure 2-3.

In the past, single crystal silicon ingots of all diameters from $0.9 \mathrm{~cm}$ to $7.5 \mathrm{~cm}$ were grown to manufacture power devices. In most power devices, the thickness of the wafer is a specific design parameter. 


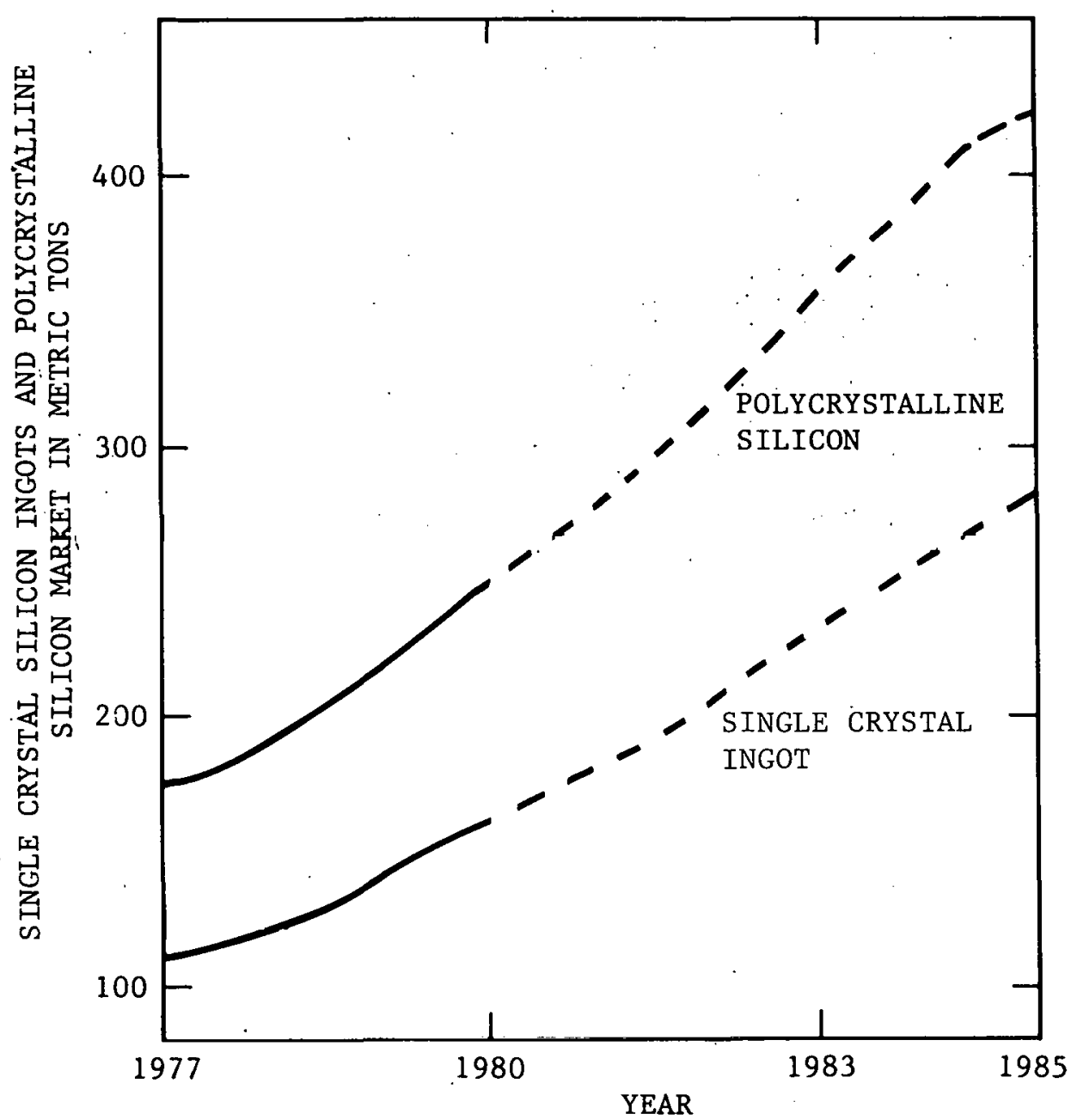

Figure 2-4. Free World Market Forecast to 1985 of Single Crystal Silicon Ingots and Polycrystalline Silicon for Power Devices

For instance, in a power rectifier, the depletion layer spreads differing distances from the junction depending upon the voltage of the alternating current being rectified. A thicker than necessary wafer just adds to $\mathrm{I}^{2} \mathrm{R}$ losses.

A good approximation of the single crystal silicon ingot necessary to provide the wafer forecast in Figure 2-3 is achieved if it is assumed that only $7.5 \mathrm{~cm}$ diameter crystal will be used and that the single crystal silicon ingot yield from polycrystalline silicon will be 75 percent.

W1th single crystal Ingot slicing, the average slice thickness will be 500 micrometers ( 0.020 inch) with a 300 micrometer ( 0.012 inch) kerf loss. The average yield of slices will be 12 per $\mathrm{cm}$ of crystal ingot length. Approximately 90 percent of the slices will meet all specifications, through all subsequent processing steps.

On the basis of these assumptions, the required amounts of single crystal silicon ingot and polycrystalline silicon for current and forecasted needs of the power device industry are shown in Figure 2-4. 
The declining price of silicon solar cell arrays (20) is beginning to expand the market for these electrical energy generation systems. As new technology and inçreased sales volume drive the cost down further, silicon solar cell arrays will become more economically practical by the late 1980s: In any business where price decrease is required for expanded business and expanded business is required for price decrease, the exact speed of market growth is difficult to predict. Therefore, three market forecasts are being made for this segment of the semiconductor device industry, shown in Figure 2-5.

\section{(1) A High Forecast}

- Projection based on the Solar Photovoltaic Energy Research, Dovelopment und Demonotration Act of 1978 (Public Law 95-590) November 4, 1978 .

(2) A Median Forecast

High probability projection of market.

\section{A Low Forecast}

A forecast based on actual orders on hand and minimum future projected market.

The most useful way to describe solar cell array performance is by the capacity to produce electrical power. The power is related to the total incident energy from the sun at any given time and the efficiency with which the solar panel converts the sunlight into electrical energy. The peak energy radiated to the earth's surface by the sun is about 1000 watts/meter ${ }^{2}$. Using this value, the number of square centimeters of … solar cell area necessary to produce one peak watt of electrical power is shown in Table 2-2.

The conversion efficiency of solar cells varics with the source of polycrystalline silicon, the type of single crystal, and the solar cell fabrication method. Solar cells fabricated from Czochralski crystal and semiconductor grade polycrystalline silicon are normally at least 13 to 14 percent efficient. The efficiency should increase to 14.5 to 15 percent by 1983 and 15 to 15.5 percent by 1985 .

Slicing practices for ingots should improve rapidly in the next few years. The slice thicknesses should decrease from 375 to 250 micrometers ( 0.015 to 0.010 inch) and the kerf loss from 300 to 240 micrometers ( 0.012 to 0.010 inch). Crystal yields, even with continuous pulling, should average 75 percent and crystal circumference grinding may be unnecessary. Using these assumptions, the amount of single:.. crystal ingot and polycrystalline silicon required to manufacture wafers for fabrication into solar cells has been calculated for the various years in Table 2-3.

From the data in Figure 2-5 and Tables 2-2 and 2-3, the single crystal ingot and polycrystalline silicon material needed for solar cell arrays can be calculated. This market forecast is presented in Tables 2-4, 2-5 and 2-6. 


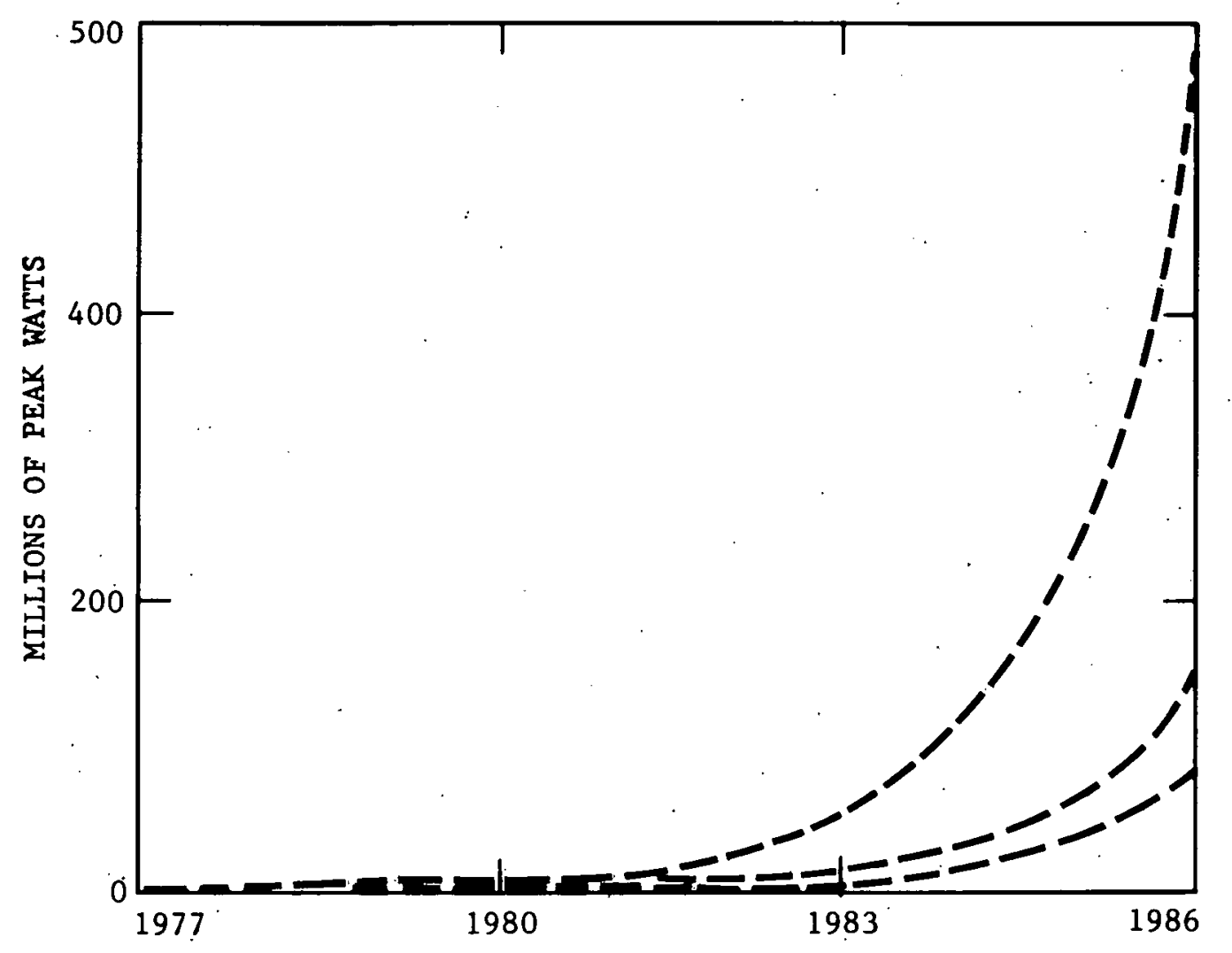

Figure 2-5. Silicon Solar Cell Array Market Projection Based on the Solar Photovoltaic Energy Research, Development and Demonstration Act of 1978, Medium, and Low Market Development Projections.

Table 2-2. Square Centimeters of Silicon Solar Cells Required to Produce One Peak Watt of Electrical Power for Various Solar Cell Efficiencies ( $1000 \mathrm{w} / \mathrm{m}^{2}$ Insolation)

\begin{tabular}{|cc}
\hline Efficienryt & Square Sentimeters \\
\hline 5 percent & 200 \\
10 percent & 100 \\
15 percent & 67 \\
16 percent & 53 \\
17 percent & 42 \\
\hline
\end{tabular}


Table 2-3. Material Forecast for Silicon Solar Cell Wafers

\begin{tabular}{cccc}
\hline Year & $\begin{array}{c}\text { Number of } \\
\text { Slices Per } \\
\text { cm of } \\
\text { Crystal }\end{array}$ & $\begin{array}{c}\text { Single Crystal } \\
\text { Silicon Required } \\
\text { Per cm of } \\
\text { Wafer }\end{array}$ & $\begin{array}{c}\text { Polycrystalline } \\
\text { Silicon Required } \\
\text { Per cm } \text { of }^{2} \\
\text { Wafer }\end{array}$ \\
\hline 1979 & 15 & 0.17 grams & 0.22 grams \\
1980 & 16 & 0.16 grams & 0.21 grams \\
1981 & 16 & 0.15 grams & 0.20 grams \\
1982 & 17 & 0.15 grams & 0.20 grams \\
1983 & 18 & 0.14 grams & 0.19 grams \\
1984 & 19 & 0.14 grams & 0.19 grams \\
1985 & 20 & 0.13 grams & 0.17 grams \\
\hline
\end{tabular}

Table 2-4. Solar P-V Energy Research, Development and Demonstration Act of 1978, (Public Law 95-590) Forecast for Flat Plate Solar Cell Arrays

\begin{tabular}{ccccc}
\hline & $\begin{array}{c}\text { Photovoltaic } \\
\text { Power } \\
\text { MWp }\end{array}$ & $\begin{array}{c}\text { Silicon } \\
\text { Wafers } \\
10^{6} \text { in }^{2}\end{array}$ & $\begin{array}{c}\text { Single } \\
\text { Crystal } \\
\text { Ingot } \\
\text { Metric Tons }\end{array}$ & $\begin{array}{c}\text { Polycrystaline } \\
\text { Silicon } \\
\text { Metric Tons }\end{array}$ \\
\hline 1979 & 4 & 286 & 48 & 60 \\
1980 & 8 & 582 & 93 & 122 \\
1981 & 16 & 1165 & 174 & 211 \\
1982 & 32 & 2257 & 338 & 420 \\
1983 & 62 & 4240 & 593 & 816 \\
1984 & 125 & 8482 & 1187 & 1580 \\
1985 & 250 & 15990 & 2078 & $2 \% 60$ \\
\hline
\end{tabular}


Table 2-5. Median Forecast for Flat Plate Solar Cell Array Delivery

\begin{tabular}{ccccc}
\hline Year & $\begin{array}{c}\text { Photovoltaic } \\
\text { Power } \\
\text { MWp }\end{array}$ & $\begin{array}{c}\text { Silicon } \\
\text { Wafers } \\
106 \mathrm{~cm}^{2}\end{array}$ & $\begin{array}{c}\text { Single } \\
\text { Crystal } \\
\text { Ingot } \\
\text { Metric Tons }\end{array}$ & $\begin{array}{c}\text { Polycrystalline } \\
\text { Silicon } \\
\text { Metric Tons }\end{array}$ \\
\hline 1979 & 2 & 143 & 24 & 31 \\
1980 & 3 & 214 & 35 & 45 \\
1981 & 8 & 579 & 87 & 113 \\
1982 & 15 & 1090 & 160 & 217 \\
1983 & 30 & 2050 & 285 & 387 \\
1984 & 50 & 3415 & 475 & 645 \\
1985 & 85 & 5772 & 750 & 980 \\
\hline
\end{tabular}

Table 2-6. Low Forecast For Flat Plate Solar Cell Array Delivery

\begin{tabular}{lcccc}
\hline Year & $\begin{array}{c}\text { Photovoltaic } \\
\text { Power } \\
\text { MWp }\end{array}$ & $\begin{array}{c}\text { Silicon } \\
\text { Wafers } \\
106 \mathrm{~cm}^{2}\end{array}$ & $\begin{array}{c}\text { Single } \\
\text { Crystal } \\
\text { Ingot } \\
\text { Metric Tons }\end{array}$ & $\begin{array}{c}\text { Polycrystalline } \\
\text { Silicon } \\
\text { Metric Tons }\end{array}$ \\
\hline 1979 & 2 & 143 & 24 & 31 \\
1980 & 2 & 143 & 23 & 30 \\
1981 & 4 & 289 & 43 & 57 \\
1982 & 10 & 728 & 108 & 146 \\
1.983 & 20 & 1367 & 190 & 258 \\
1984 & 30 & 2048 & 286 & 386 \\
1985 & 50 & 3395 & 440 & 577 \\
\hline
\end{tabular}




\section{A. POLYCRYSTALLINE SILICON}

Polycrystalline silicon production from 1977 - 1978 and projected capacity of free world plants to produce polycrystalline silicon to 1985 were determined by visits and telephone interviews with the major companies: Wacker, Hemlock Semiconductor (Dow), Texas Instruments, Monsanto, Smiel, Motorola and Great Western. The results are presented in Table 3-1 and plotted in Figure 3-1.

Table 3-1. Polycrystalline Silicon: Free World Existing and Planned Plant Capacity (In Metric Tons)

\begin{tabular}{|c|c|c|c|c|c|c|c|c|c|}
\hline Plant & 1977 & 1978 & 1979 & 1980 & 1981 & 1982 & 1983 & 1984 & 1985 \\
\hline Wacker (Germany) & 700 & 700 & 700 & 800 & 850 & 875 & 875 & 875 & 875 \\
\hline Dow Corning. & 500 & 500 & 500 & 700 & 775 & 850 & $900^{\circ}$ & 950 & 1000 \\
\hline Texas Instruments & 175 & 175 & 200 & 250 & 275 & 300 & 325 & 325 & 325 \\
\hline Monsanto & 175 & 190 & 200 & 210 & 220 & 230 & 230 & 230 & 230 \\
\hline Smiel (Italy) & 150 & 175 & 190 & 200 & 210 & 220 & 230 & 230 & 230 \\
\hline Motorola & 100 & 100 & 100 & 100 & 100 & 100 & 100 & 100 & 100 \\
\hline Topsil (Denmark) & 15 & 15 & 20 & 25 & 25 & 25 & 25 & 25 & 25 \\
\hline Siemens (Germany) & 10 & . 10 & 10 & 10 & 10 & 10 & 10 & 10 & 10 \\
\hline Great Western & - & 10 & 50 & 100 & 120 & 140 & 150 & 150 & 150 \\
\hline Japan & 280 & 254 & 300 & 300 & 300 & 300 & 300 & 300 & 300 \\
\hline $\begin{array}{l}\text { Total Acceptable } \\
\text { Integrated Circuit } \\
\text { and Power Device } \\
\text { Capacity Not } \\
\text { Including Reprocess } \\
\text { Material }\end{array}$ & $\begin{array}{l}2105 \\
\text { sed }\end{array}$ & 2129 & 2270 & 2695 & 2885 & 3050 & 3145 & 3195 & 3245 \\
\hline
\end{tabular}

Industry capacity is usually about $15 \%$ more than is acceptable for the integrated circuit and power device manufacturers. This material is either reprocessed or purchased by the photovoltaic industry for production of solar cells. 


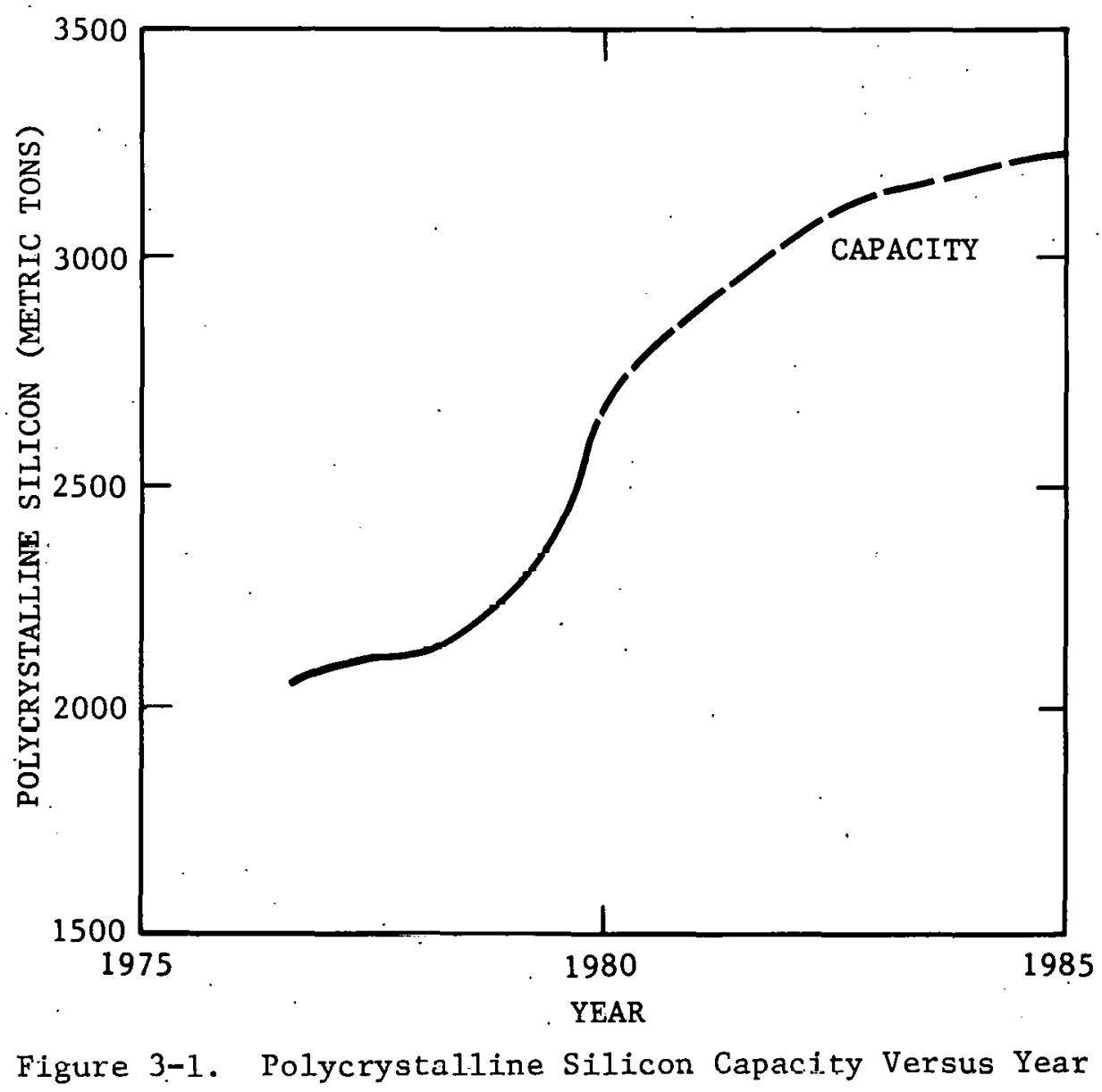

In general, the companies expressed a strong concern for polycrystalline silicon availability, and predicted a likely shortage during the critical years, 1980-85. The companies also indicated little immedate interest in building new Siemens technology plants or financing expansions until the results of the new technologies (funded by DOE) under development are known.

The polycrystalline silicon plants throughout the free world are primarily Siemens technology plants that were built after 1967. Some of these plants are the result of the polycrystalline silicon shortage of 1973-1974. (21-22-23)

All polycrystalline silicon plants are run around the clock, seven days per week. The typical polycrystalline reactor grows silicon rods, approximately $105 \mathrm{~cm}$ long and $10 \mathrm{~cm}$ in diameter during a ten day period. This is a rate of one hundred and sixty usable kilograms per run or approximately five metric tons per year.

The capacity of a polycrystalline silicon plant can be increased by up to $20 \%$ by increasing on-stream periods of reactant flow and by using pure trichlorosilane as a reactant. In times of product shortage, such procedures are followed. 
Since the Siemens process to manufacture polycrystalline silicon is strictly a batch operation using small reactors, simple bigness is no major advantage (beyond a certain size). To produce more product, more reactors are needed.

The process flow of a typical polycrystalline silicon plant is shown in Figure 3-2. While such plants are quite standard in design, they are usually run in a custom manner to optimize quantity, reaction yield, or product appearance.

The cost of polycrystalline silicon produced by the Siemen's process in a fully depreciated plant is about $\$ 40 / \mathrm{kg}(5)$. The average price of such silicon on July 1,1979 was $\$ 63 / \mathrm{kg}(6)$. The construction cost of a new 100 metric ton per year plant using this technology would be $\$ 20,000,000$. The cost to manufacture silicon in such a new plant for the first year is detailed below.

Cost of Manufacturing Polycrystalline Silicon New Plant - Old Technology (Siemens)

Power at $\$ 0.03 / \mathrm{kwh}$

$\mathrm{SiHCl}_{3}$ at 3 cents/gram $\mathrm{H}_{2}$ at $\$ 0.80 / 100 \mathrm{cu}$. $\mathrm{ft}$.

Supplies

Maintenance and Engineering

Wages

Salaries

Miscellaneous

Depreciation 10 years straight line
$\$ 8.00 / \mathrm{kg}$

$17.00 / \mathrm{kg}$

$2.00 / \mathrm{kg}$

$4.00 / \mathrm{kg}$

$4.00 / \mathrm{kg}$

$2.50 / \mathrm{kg}$

$1.00 / \mathrm{kg}$

$1.50 / \mathrm{kg}$

$20.00 / \mathrm{kg}$

Cost

$\$ 60.00 / \mathrm{kg}$.

For integrated circuits where polycrystalline silicon is approximately one percent of manufacturing cost, this is not too far out of line. For solar cell arrays, polycrystalline silicon is a much larger portion of the total cost. At a price of $\$ 60 / \mathrm{kg}$, there can be no economic, widespread terrestrial electrical power generation from flat plate solar: cell arrays assuming present fossil fuel price projections.

It is highly unlikely that the industry will invest in new silicon production capacity which is centered on the presently-used siemensprocess. The main arguments against such new installations are: (1) The total product cost of silicon from new Siemens-process plants would be significantly greater than from existing plants (which were installed in the 1967 to 1974 period and are mostly depreciated). Higher costs would probably necessitate commensurately higher prices to allow for an acceptable.profit and a reasonable write-off time. Also, the uncertainty of adequately high prices at the appropriate times discourages investments in new plants. Commercial feasibility is too uncertain to encourage plans for these installations. (2) Progress has been made in the Low Cost Solar Array Project (under a DOE contract to JPL) in developing new 
PROCESS FLOW

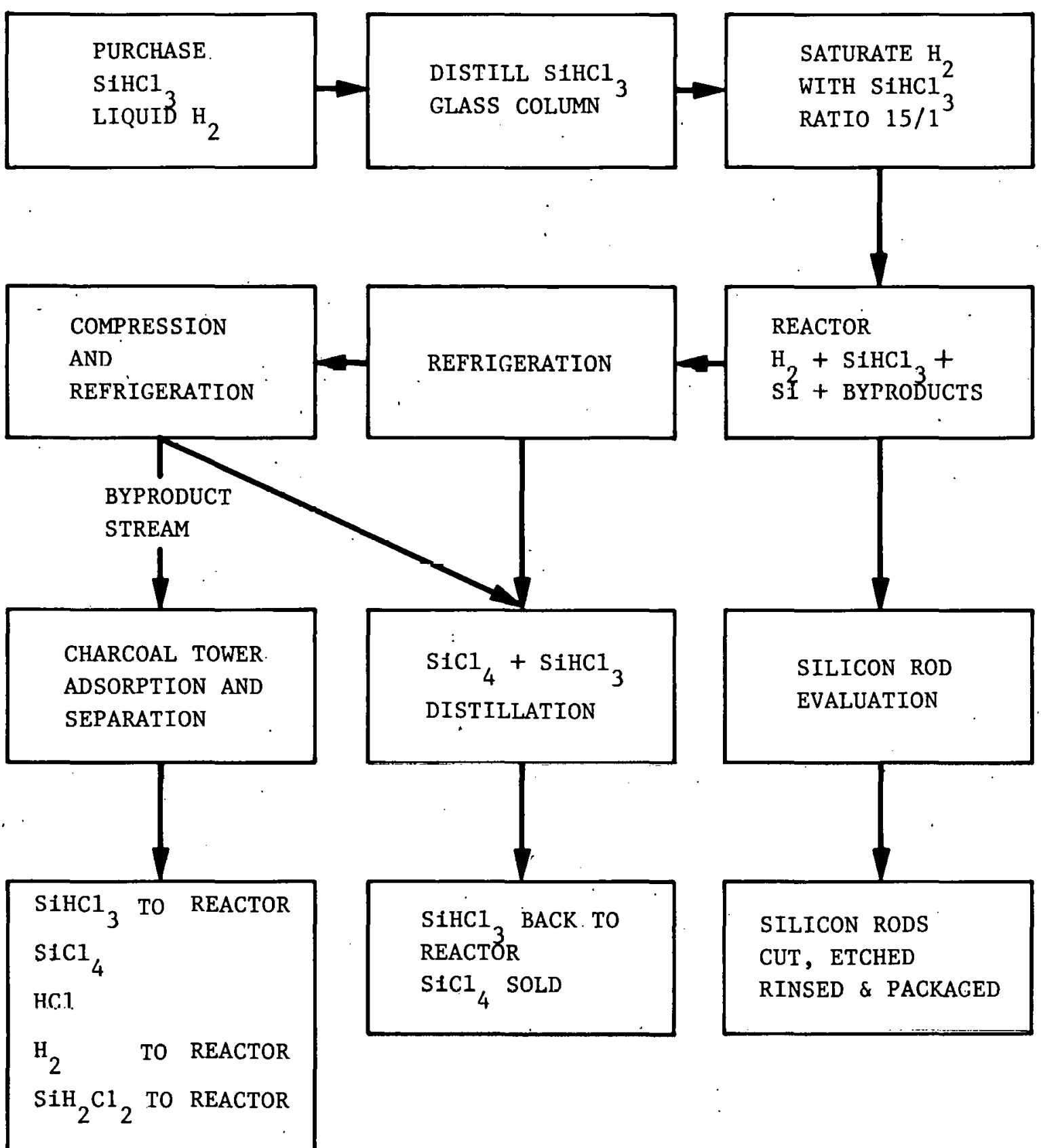

Figure 3-2. The Manufacturing Process Flow for a Typical' Siemens Polycrystalline Silicon Plant 
processes to produce low cost, semiconductor grade silicon. There is a high probability that the 1986 price goal $(\$ 14 / \mathrm{kg}$ compared to about $\$ 65 / \mathrm{kg}$ in $\$ 1980$ ) will be achieved by one or more of these processes. Hence, the likelihood that a new process will be used in silicon production plants about 1986 leads to a reluctance to invest in new Siemens-process capacity.

Establishing the practicality for new low-cost silicon processes for terrestrial solar arrays is pursued under the Low-Cost Solar Array Project, sponsored by DOE and managed by the Jet Propulsion Laboratory. This work started in 1975; the technology developments have progressed to the phase where technology readiness will be demonstrated by the end of FY-82. At this time, the information base will be available for decisions on installation of large production plants. There is a high probability that the goal will be achieved of a market price less than $\$ 14 / \mathrm{kg}$ silicon (1980\$).

The direct arc reduction of silicon dioxide with carbon is used today to manufacture electrometallurgical-grade silicon for use in alloying steels, and as a raw material to manufacture silicon tetrachloride, trichlorosilane, and dichlorosilane. Metallurgical-grade silicon with less than one percent impurițies is manufactured today for less than $\$ 1.00 / \mathrm{kg}$. It is possible that a purified grade of metallurgicaltype polycrystalline silicon could be produced of suitable quality for solar cell production for a cost of $\$ 2 / \mathrm{kg}-\$ 5 / \mathrm{kg}$. However, such silicon has little chance of being converted cost effectively to single crystal by the Czochralski or the Floating Zone process. The material could be solidified by directional cooling (9) where some of the impurities would be immobilized at grain boundaries. Because solar cells from such silicon would be less efficient than solar cells from Czochralski single crystal, and since the sawing process is still necessary, such silicon must be produced considerably less expensively than semiconductor-grade silicon to be a commercially viable product.

During the next few years, the solar cell industry will require polycrystalline silicon for experimentation and demonstration projects. To obtain this material, the industry must depend upon the same silicon suppliers as the integrated circuits industry. A projected shortage of materials for one industry, will result in a shullage uf materials for the other industry. However, the integrated circuits industry can afford to pay a higher price per kilogram of polycrystalline silicon than the solar cell industry. This is true only because the solar cell industry is material intensive and the integrated circuits industry is not. 


\section{B. SINGLE CRYSTALS SILICON INGOTS AND WAFERS}

Results of the survey of free world capacity to grow single crystal silicon ingots and to slice wafers are presented in Table 3-2 and plotted in Figures 3-3 and 3-4. Specific data for installed and operating crystal growth systems in the U.S. are listed by individual company in Table 3-3.

There are 191 systems in the U.S. capable of growing $7.5 \mathrm{~cm}$ diameter crystals and 172 systems capable of growing $10 \mathrm{~cm}$ diameter crystals. The annual crystal growth capacity of the United States on May 1, 1979 had increased to an approximate level of 1100 metric tons. Japan and Europe together have a greater crystal growth capacity since both of these areas are net exporters to the United States. Planned expansions in the U.S. alone will add another 1000 metric tons to annual crystal growth capacity.

The crystal growth system industry (Hamco, Leybold Heraeus, Siltec and Varian) is now eastly capable of manufacturing 200 new growth systems per year. The 200 new crystal growth systems certainly would be capable of producing 1000 metric tons of single crystal ingot per year. With advance planning, the crystal growth industry could produce as many systems as needed.

Table-3-2. Free World Existing Plant Capacity for Single Crystal Silicon Ingots and Wafers

\begin{tabular}{ccc}
\hline Year & $\begin{array}{c}\text { Single Crystal Silicon } \\
\text { Ingots (Metric Tons) }\end{array}$ & $\begin{array}{c}\text { Wafers } \\
10^{6} \mathrm{ch}^{2}\end{array}$ \\
\hline 1977 & 1400 & 8194 \\
1978 & 1600 & 9355 \\
1979 & 2400 & 14065 \\
1980 & 3000 & 19355 \\
1981 & 3500 & 22580 \\
1982 & 4000 & 25806 \\
1983 & $*$ & $*$ \\
1984 & $*$ & $*$ \\
1985 & $*$ & $*$ \\
\hline
\end{tabular}

*potential expansion beyond 1982 not available 


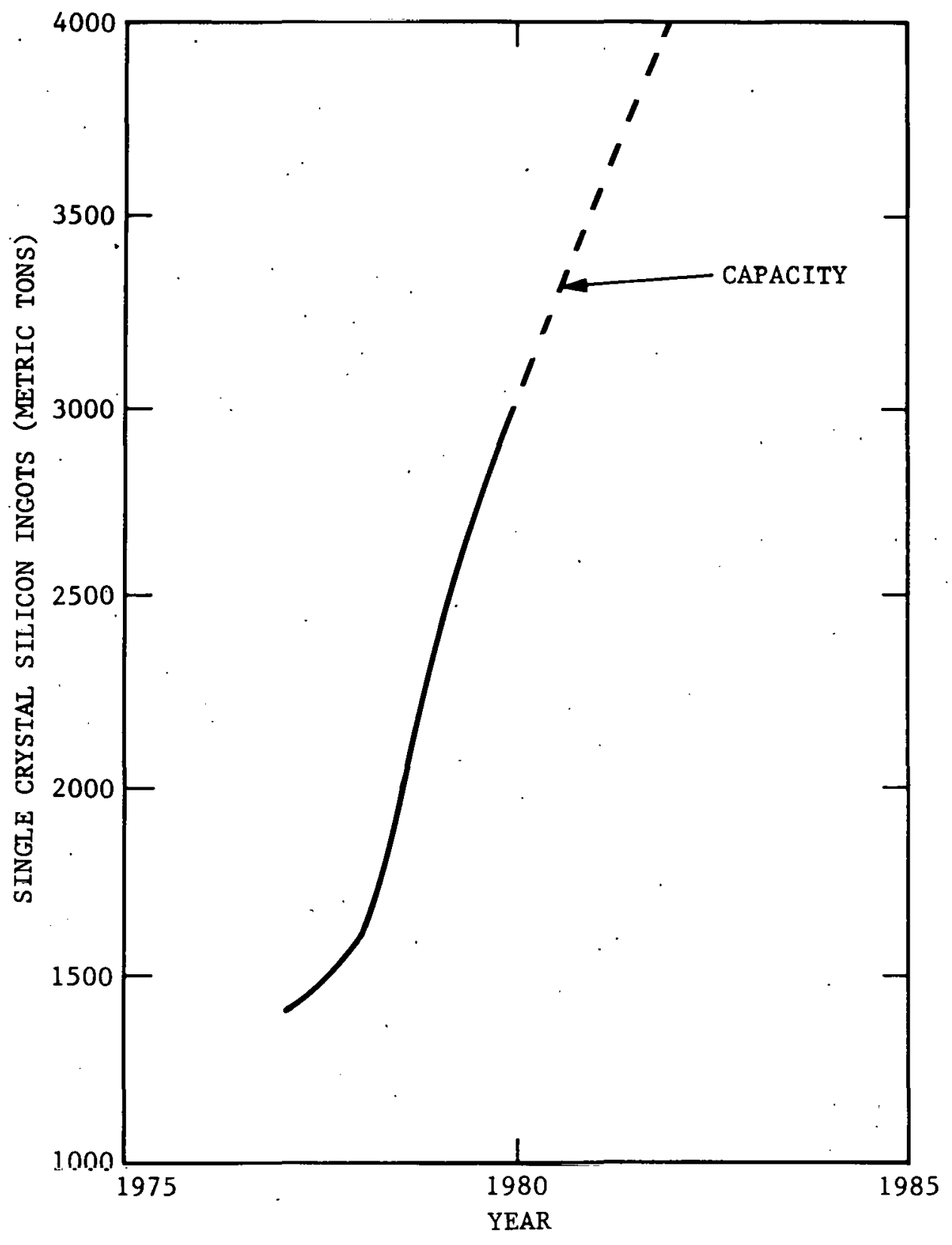

Figure 3-3. Single Crystal S1licon Ingot Capacity Versus Year 


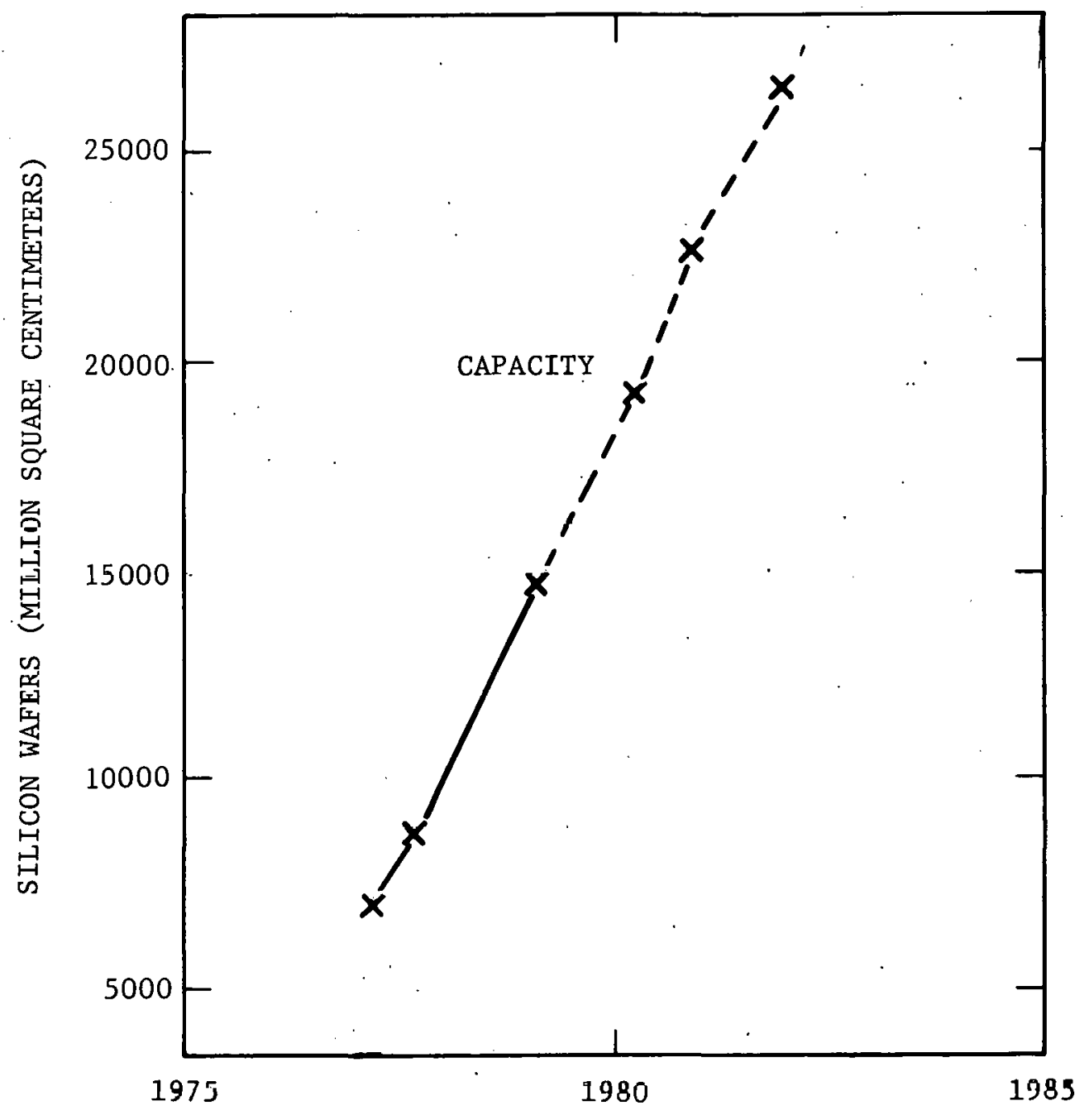

Tlgure 3-4. S1llcun Wafer Capac1zy Versus Year 
Table 3-3. Installed and Operating Single Crystal Silicon Ingot Growth Systems of Major U.S. Producers

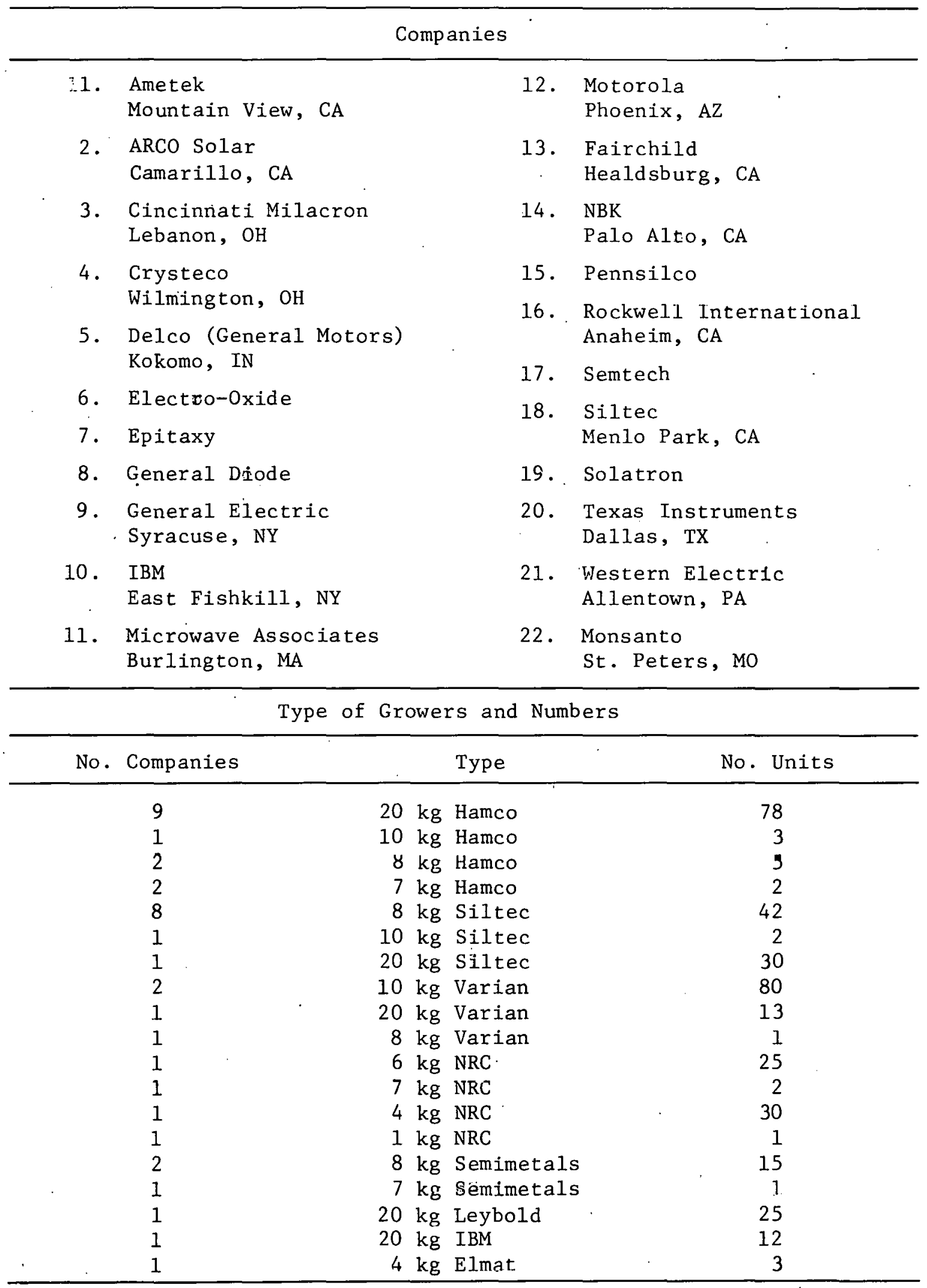


The capacity to slice, bevel, lap, etch, polish and clean wafers follows crystal growth capacity exactly. These capacities are, and will continue to be, in line with crystal growth capacity.

\section{SINGLE CRYSTAL INGOT AND WAFERING. QUESTIONNAIRE REVIEW}

An important aspect of this study was to evaluate questionnaires (Appendix B) which had been submitted to various silicon material suppliers, silicon processing equipment manufacturers, and solar cell manufacturers. Due to incomplete replies and unreturned questionnaires, it would be difficult if not impossible to develop quantitative predictions of needs and capabilities. However, the responses are sufficient to provide backup for quantitative data obtained from other sources and to discern general trends.

The availability of polycrystalline silicon is obviously critical to the ingot growing and wafering industries. All respondents expressed general agreement that present day availability is not a problem or at worst is an inconvenience necessitating 5-6 months order lead time. There was also agreement that polycrystalline silicon availability will beculle d problem by 1982-3. Any shortage rould obviously impact. unfavorably the present price range of $\$ 54-90$ per kilogram. The impact of a possible solar-grade silicon on the market was acknowledged as uncertain. Because of the dominance of the silicon material market by the semiconductor device manufacturers who need highly pure and damage free silicon, it would appear that little will be done to provide solargrade material without a substantial impetus from government or the solar cell industry.

The majority of respondents and silicon material suppliers heavily depend upon, and cater to, the semiconductor device industry; an industry whose objectives are quite different from those of the solar cell industry. As the solar cell industry grows and develops its own specialized processes and requirements, the supporting semiconductor industries will become less capable of providing assistance, unless specific efforts " are made to provide compatible solar cell services.

There was little response to the question on present crystal growing ingot manufacturing capacity. However, there was overwhelming, consensus that the size of ingots and wafers will increase. At present, the normal ingot diameter is from 75 to $100 \mathrm{~mm}$. By 1980 and 1981, $125 \mathrm{~mm}$ ingots will be introduced, with $150 \mathrm{~mm}$ diameter predicted for the period 1982-85. Equipment suppliers and users think that these sizes are reasonable over the listed time periods. One crystal grower and one wafer slicer mentioned the anticipated growth of $200 \mathrm{~mm}$ diameter ingots within 1981-85. Whether such large sizes will be useful to the solar cell industry is open to debate, but they clearly reflect desires of the semiconductor device manufacturers.

Current prices for silicon wafers were $\$ 0.04 / \mathrm{cm}^{2}$ for as-sawn and $\$ 0.12-\$ 0.23 / \mathrm{cm}^{2}$ for polished wafers of average thickness and 
resistivity tolerance. Little change in price was anticipated for 1982 with one respondent predicting an increase in price ( $<20$ percent). Prices for 1986 were thought to be unpredictable at this point because of the diverse effects of inflation, ingot and wafer size increases, and market size.

Little comment was made on production problems although it was acknowledged that thinner and larger diameter wafers will cause yield losses for wafer producers. The use of I.D. saws was clearly felt to continue to provide the most useful sawing technique.

The present order backlog for ingot and wafer suppliers ranged from 3 to 7 months with future reductions anticipated. Suppliers of ingot growers and saws indicate a slightly longer backlog, with none of the material or equipment respondents maintaining warehouse stocks. This "make to order" philosophy reflects the rapidly changing technology characteristics of the semiconductor device industry.

In view of the rapid growth of the semiconductor industry, respondents indicate planned continued expansion. Some of the largest increases are mentioned by wafer suppliers and saw manufacturers, i.e., 2100 percent within three years. The means of achieving higher production is due not only to additional equipment purchases, but also to larger ingot sizes. Although larger ingot volumes were also mentioned, responses about melt replenishment during the next five years showed no consensus.

To support processing growth, equipment manufacturers are planning on increased output. Although expansions of $50 \%$ are scheduled over the next few years, the suppliers' attitudes are aggressive. A crystal grower commented that they could easily triple output if a long term (2+ years) market evolved and a saw manufacturer responded that they could expand to meet any market with a one year reaction time. In view of the lack of new companies entering the field (one exception mentioned is Ametek), it is evident that growth of the existing organizations is necessary for meeting any increased demands.

During the next five years, there is little expectation of significant contributions from any of the potentially new processes. Awareness of the DOE programs was expressed and evaluations are being made.

From the DOE-forecast photovoltaic procurement plan (Public Law 95-590) presented and the questionnaire, it was widely stated that only short term ( $1-3$ years) procurement plans could be met by the present polycrystalline plant capacity. Beyond that, a heavy investment would be required. In any event, staggered orders and long range procurement contracts are definilely preferred.

To the present, the solar cell industry has been a small outlet for the semiconductor supplier industry, not a consistent nor large customer. The ingot and wafer-related industries appear to be flexible enough to take on additional demands imposed by the DOE solar iell programs given a reasonable lead time. In addition, further wafering capacity presently exists in associated areas such as the quartz industry, which has responded in a positive manner to the idea of taking 
on additional business in silicon wafering. At the same time, there is a definite and dynamic trend by the solar cell manufacturers to grow and slice their own silicon. The combination of these resources should provide for sufficient, if not excessive capacity in these areas, although in-house expansion of solar cell manufacturers may remove some expansion incentive from semicondictor ingot and wafer suppliers. In the long run, it appears that the silicon needs of the solar cell industry will be different enough from the semiconductor industry to require completely separate sources for silicon materials and possibly, equipment. 


\section{SECTION IV}

COMPARISON OF CAPACITY AND MARKET NEEDS

\section{A. POLYCRYSTALLINE SILICON}

A comparison of current and forecast capacity and product consumption of polycrystalline silicon is made. in Table 4-1 and Figure 4-1. The data indicate a large oversupply of polycrystalline silicon in 1977 going to a shortage in 1982. The supply situation is such that from 1979-1982, extreme discipline is required to match supply and need. After 1982; a shortage is predicted.

Because of this shortage of fabricating material for integrated circuits and power devices, very little polycrystalline silicon is likely to be available for solar cells. However, typically, some polycrystalline silicon is manufactured that doesn't meet the specifications of the semiconductor industry. Also, some Czochralski crystals are grown that don't meet specifications.

This non-conforming material is usually the source of single crystal ingots for silicon solar cells. About $15 \%$ of the capacity of the polycrystalline silicon industry is usually available to the solar cell industry from these sources. Table 4-2 presents data on availability of non-conforming silicon with anticipated needs for the solar cell Industry to meet the (Public Law 95-590) demands.

Table 4-1. Polycrystalline Silicon (Without Solar): Comparison of Capacity and Market Needs (In Metric Tons)

\begin{tabular}{lcccc}
\hline Year & $\begin{array}{c}\text { Integrated } \\
\text { Circuit } \\
\text { Market }\end{array}$ & $\begin{array}{l}\text { Power } \\
\text { Device } \\
\text { Market }\end{array}$ & $\begin{array}{c}\text { Total } \\
\text { Non-Solar } \\
\text { Market }\end{array}$ & $\begin{array}{c}\text { Capacity } \\
\text { To } \\
\text { Produce }\end{array}$ \\
\hline 1977 & 1050 & 178 & 1128 & 2105 \\
1978 & 1.345 & 188 & 1533 & 2129 \\
1979 & 1854 & 220 & 2042 & 2270 \\
1980 & 2110 & 247 & 2357 & 2695 \\
1981 & 2400 & 280 & 2680 & 2885 \\
1982 & 2736 & 320 & 3056 & 3050 \\
1983 & 3055 & 360 & 3415 & $31 / 5$ \\
1984 & 3415 & 400 & 3815 & 3195 \\
1985 & 3780 & 440 & 4220 & 3245 \\
\hline
\end{tabular}




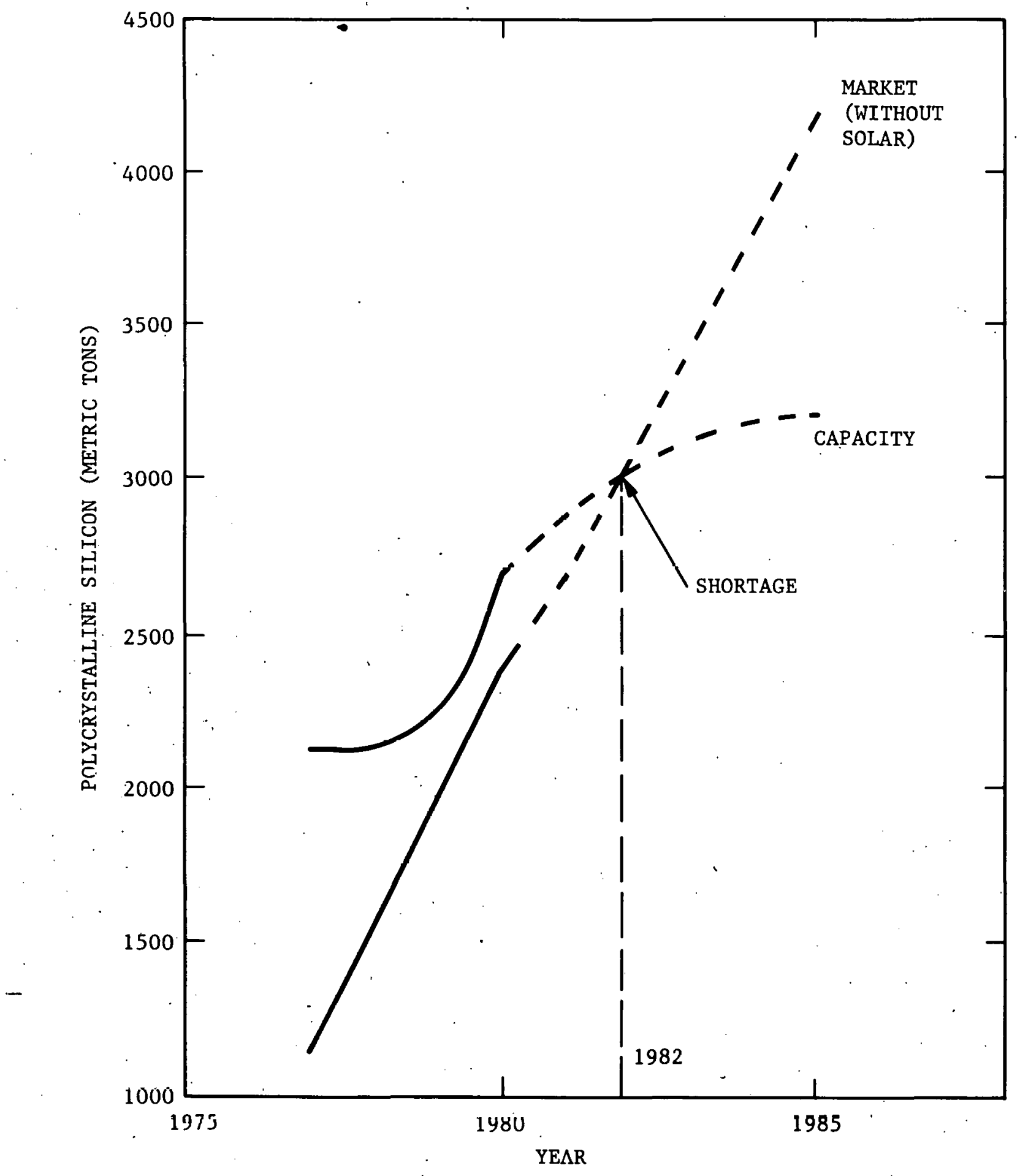

F'igure 4-1. Comparison of Market and Capacity for Polycrystalline Silicon (Without Solar) 
Table 4-2. Polycrystalline Silicon Solar Capacity and Market Needs (Metric Tons)

\begin{tabular}{lrc}
\hline Year & $\begin{array}{c}\text { Solar* } \\
\text { Market }\end{array}$ & $\begin{array}{c}\text { Non-Conforming** Polycrystalline } \\
\text { Silicon Capacity }\end{array}$ \\
\hline 1977 & 8 & 316 \\
1978 & 16 & 330 \\
1979 & 60 & 340 \\
1980 & 122 & 405 \\
1981 & 211 & 435 \\
1982 & 420 & 460 \\
1983 & 816 & 470 \\
1984 & 1580 & 480 \\
1985 & 2760 & 490 \\
\hline
\end{tabular}

*For PV power capacity given in Table 2-4.

**Non-conforming to integrated circuits specification.

Tables 4-3, 4-3a, 4-3b and Figure 4-2 compare market need with the capacity to produce polycrystalline silicon for both solar cells and non-solar devices (integrated circuits and power devices). The data. indicate a polycrystalline silicon shortage beginning in 1981 (without non-conforming material availability) and in 1982 (with non-conforming material availability). Both shortage projections emphasize the critical supply situation for polycrystalline silicon. for solar cells in the 1983-85 time period.

\section{B. SINGLE CRYSTAL SILICON INGOTS AND WAFERS}

A comparison of the current and future market and capacity to produce single crystal silicon ingots is made in Table 4-4 and Figure 4-3. The same type comparison is presented in Table 4-5. and Figure 4-4 for silicon wafers. Both comparisons include silicon for solar cells and non-solar devices (integrated circuits and power devices). Figure 4-4 indicates that there is not likely to be a capacity shortage to produce sllicon wafers in the critical 1980-85 time period if polycrystalline silicon can be made avallable.

With all three forccasts for flat-plate solar cell arrays, the forecast capacity to grow single crystal silicon ingots is adequate without the unannounced expansions beyond 1982. There is more than sufficient time to gear up for 1986 and future market requirements. 
For wafers, the capacity to slice, lap, and polish single crystal ingots will follow ingot growth capacity and will be ready as needed.

Table 4-3. Polycrystalline Silicon (Solar and Non-Solar): Comparison of Capacity and Market Needs For High Forecast (Metric Tons)

\begin{tabular}{cccccc} 
Year & $\begin{array}{c}\text { Non-Solar } \\
\text { Market }\end{array}$ & $\begin{array}{c}\text { Solar* } \\
\text { Market }\end{array}$ & $\begin{array}{c}\text { Total } \\
\text { Market }\end{array}$ & $\begin{array}{c}\text { Capacity to Produce } \\
\text { Without } \\
\text { Non-Con- } \\
\text { forming** }\end{array}$ & $\begin{array}{c}\text { With } \\
\text { Non-Con- } \\
\text { forming** }\end{array}$ \\
\hline 1977 & 1128 & 8 & 1136 & 2.105 & 2470 \\
1978 & 1533 & 16 & 1550 & 2129 & 2459 \\
1979 & 2042 & 60 & 2102 & 2270 & 2610 \\
1980 & 2357 & 122 & 2479 & 2695 & 3100 \\
1981 & 2680 & 211 & 2891 & 2885 & 3320 \\
1982 & 3056 & 420 & 3476 & 3050 short- 3510 short- \\
1983 & 3415 & 816 & 4231 & 3145 & 3615 \\
1984 & 3815 & 1580 & 5395 & 3195 & 3675 \\
1985 & 4220 & 2760 & 6980 & 3245 & 3775
\end{tabular}

* For PV power capacity given in Table 2-4 $* *$ Non-conforming to integrated circuits specification. 
Table 4.3a. Polycrystalline Silicon (Solar and Non-Solar): Comparison of Capacity and Market Needs For Median Forecast (Metric Tons)

\begin{tabular}{lccccc}
\hline & & & & \multicolumn{2}{c}{ Capacity } \\
\cline { 5 - 6 } Year & $\begin{array}{c}\text { Non-Solar } \\
\text { Market }\end{array}$ & $\begin{array}{c}\text { Solar* } \\
\text { Market }\end{array}$ & $\begin{array}{c}\text { Total } \\
\text { Market }\end{array}$ & $\begin{array}{c}\text { Without } \\
\text { Non-Conforming** }\end{array}$ & $\begin{array}{c}\text { With } \\
\text { Non-Conforming** }\end{array}$ \\
\hline 1977 & 1128 & 8 & 1136 & 2105 & 2420 \\
1978 & 1533 & 16 & 1550 & 2129 & 2459 \\
1979 & 2042 & 31 & 2072 & 2270 & 2610 \\
1980 & 2357 & 45 & 2402 & 2695 & 3100 \\
1981 & 2680 & 113 & 2793 & 2885 & 3320 \\
1982 & 3056 & 217 & 3273 & 3050 & 3510 \\
1983 & 3415 & 387 & 3802 & 3145 & 3615 Shortage \\
1984 & 3815 & 645 & 4460 & 3195 & 3675 \\
1985 & 4220 & 980 & 5200 & 3245 & 3775 \\
\hline
\end{tabular}

*For PV power capacity given in Table 2-5. **Non-conforming to integrated circuits specification.

Table 4.3b. Polycrystalline Silicon (Solar and Non-Solar): Comparison of Capacity and Market Needs For Low Forecast (Metric Tons)

\begin{tabular}{lccccc}
\hline & & & \multicolumn{2}{c}{ Capacity } & to Produce \\
\cline { 5 - 6 } Year & $\begin{array}{c}\text { Non-Solar } \\
\text { Market }\end{array}$ & $\begin{array}{c}\text { Solar* } \\
\text { Market }\end{array}$ & $\begin{array}{c}\text { Total } \\
\text { Market }\end{array}$ & $\begin{array}{c}\text { Without } \\
\text { Non-Conforming** }\end{array}$ & $\begin{array}{c}\text { With } \\
\text { Non-Conforming** }\end{array}$ \\
\hline 1977 & 1128 & 8 & 1136 & 2105 & 2420 \\
1978 & 1533 & 16 & 1550 & 2129 & 2454 \\
1979 & 2042 & 31 & 2073 & 2270 & 2610 \\
1980 & 2357 & 30 & 2387 & 2695 & 3100 \\
1981 & 2680 & 57 & 2737 & 2885 & 3320 \\
1982 & 3056 & 146 & 3202 & 3050 Shortage & $3510 \quad \therefore$ \\
1983 & 3415 & 258 & 3673 & 3145 & 3615 Shortage \\
1984 & 3815 & 386 & 4201 & 3195 & 3675 \\
1985 & 4220 & 577 & 4797 & 3245 & 3775 \\
\hline
\end{tabular}

* For PV power capacity given in Table 2-6 $* *$ Non-conforming to integrated circuits specification. 


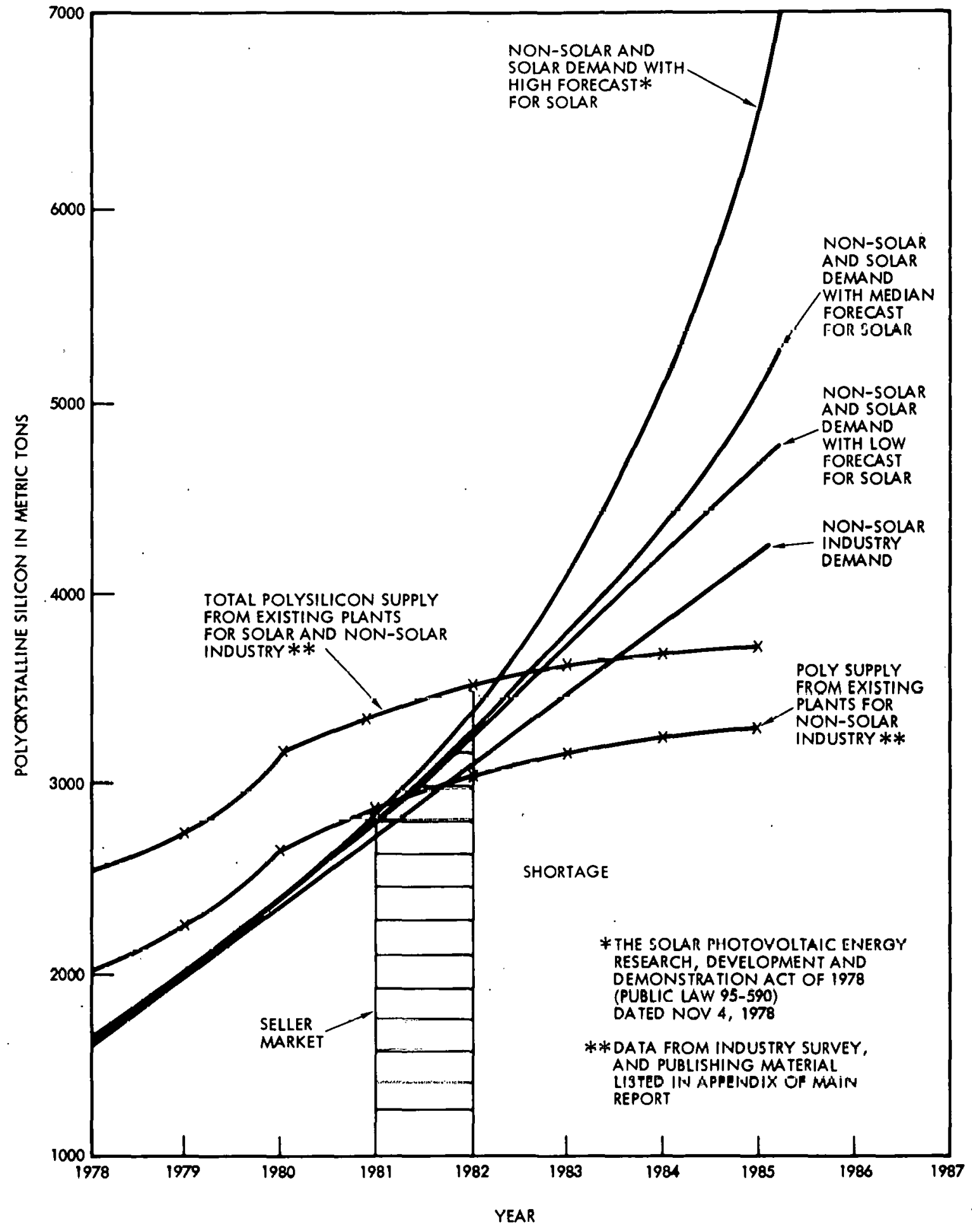

Figure 4-2. Current and Prujected Polycrystal Material Supply and Demand Requirements 
Table 4-4.' Single Crystal Silicon: Comparison of Capacity and Market Needs (Metric Tons)

\begin{tabular}{ccccc}
\hline Year & $\begin{array}{c}\text { Non-Solar } \\
\text { Market }\end{array}$ & $\begin{array}{c}\text { Solar* } \\
\text { Market }\end{array}$ & $\begin{array}{c}\text { Total } \\
\text { Market }\end{array}$ & $\begin{array}{c}\text { Capacity } \\
\text { To } \\
\text { Produce }\end{array}$ \\
\hline 1977 & 786 & 6 & 792 & 1400 \\
1978 & 982 & 12 & 994 & 1600 \\
1979 & 1323 & 24 & 1347 & 2400 \\
1980 & 1504 & 59 & 1563 & 3000 \\
1981 & 1712 & 112 & 1824 & 3500. \\
1982 & 1953 & 273 & 2226 & 4000. \\
1983 & 2179 & 742 & 2921 & $* * *$ \\
1984 & 2465 & 1185 & 3650 & $* *$ \\
1985 & 2700 & 2067 & 4767 & $* *$ \\
\hline
\end{tabular}

*For solar capacity given in Table 2-4.

**Industry expansion plans beyond 1982 not available. 


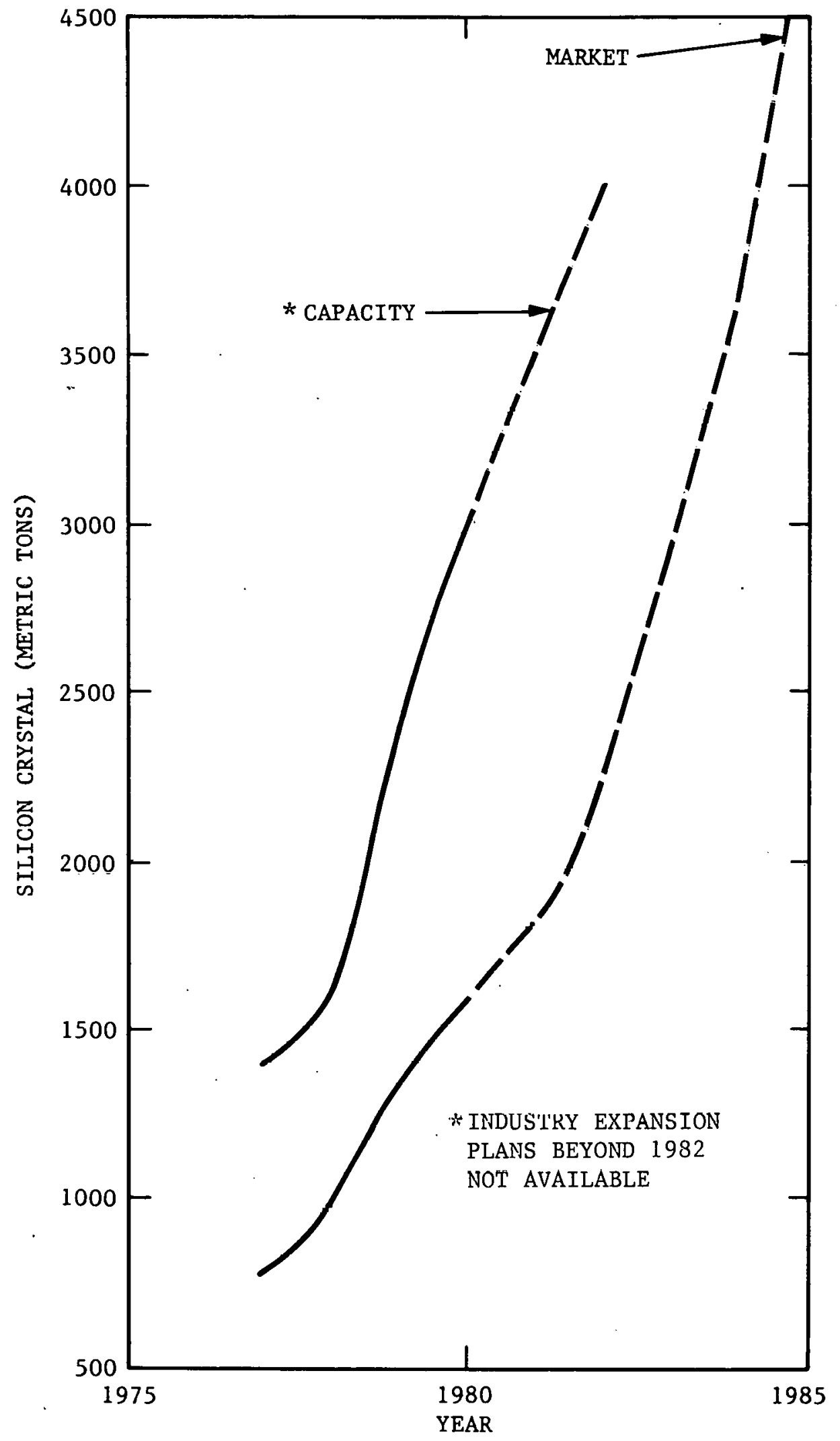

Figure 4-3. Comparison of Market and Capacity for Single Crystal Silicon 
Table 4-5. Silicon Wafers: Comparison of Market and Capacity $\left(10^{6} \mathrm{~m}^{2}\right)$

\begin{tabular}{ccccc}
\hline Year & $\begin{array}{c}\text { Non-Solar } \\
\text { Market }\end{array}$ & $\begin{array}{c}\text { Solar* } \\
\text { Market }\end{array}$ & $\begin{array}{c}\text { Total } \\
\text { Market }\end{array}$ & $\begin{array}{c}\text { Capacity } \\
\text { To } \\
\text { Produce }\end{array}$ \\
\hline 1977 & 0.280 & 0.003 & 0.283 & 0.82 \\
1978 & 0.340 & 0.007 & 0.347 & 0.93 \\
1979 & 0.443 & 0.014 & 0.457 & 1.4 \\
1980 & 0.490 & 0.035 & 0.535 & 1.93 \\
1981 & 0.541 & 0.070 & 0.611 & 2.25 \\
1982 & 0.600 & 0.175 & 0.775 & 2.58 \\
1983 & 0.662 & 0.493 & 1.155 & $* *$ \\
1984 & 0.731 & 0.822 & 1.553 & $* *$ \\
1985 & 0.800 & 1.54 & 2.340 & $* *$ \\
\hline$*$ Ref. Table & $2-4 * *$ & Industry expansion plans beyond & 1982 \\
\hline
\end{tabular}




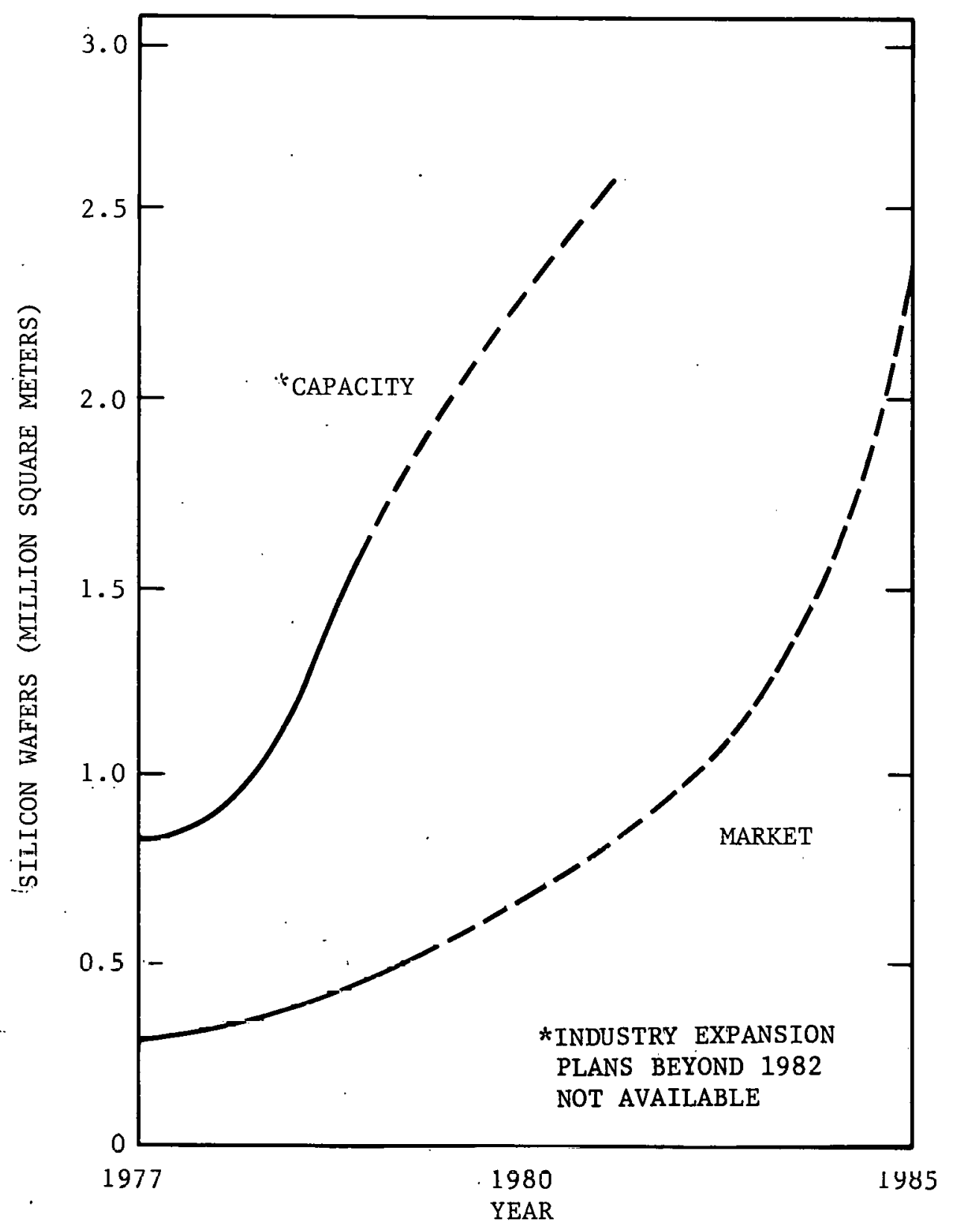

Figure 4-4. Comparison of Capacity and Market for Silicon Wafers 


\title{
SECTION $V$
}

\author{
INFLUENCING ECONOMIC AND TECHNICAL FACTORS
}

\section{A. ECONOMIC CONSIDERATIONS}

Polycrystalline silicon must be available in sufficient quantity at costs of $\$ 14 / \mathrm{kg}$ (1980 dollars) or less to meet the cost and demand goals of DOE for photovoltaic modules. The supply of polycrystalline silicon based on existing facilities is expected to be equal to the demand of the non-solar industry by 1982. Because of the anticipated shortage of polycrystalline silicon, new technology DOE-sponsored pilot plants now anticipated to be built during 1980-1985 are not likely to be." of sufficient capacity to relieve the shortage and thus, the cost of the material will remain high. The non-solar industry can afford to pay more for polycrystalline silicon than the photovoltaic industry since, for them, the cost of silicon material is a much smaller fraction of the total cost of the device. The cost of polycrystalline silicon is not expected to drop to the desired level of $\$ 14 / \mathrm{kg}$ until the silicon supply is primarily from large plants based on new technology. The earliest time for large, new technology plants to come on-line would be approximately 1986. The cost of building plants capable of producing 1000 metric tons would be about $\$ 45$ million (1980 dollars) each. Further, industry interviews revealed that the semiconductor device industry and the developing photovoltaic industry prefer to operate with the vertical integration approach to compete for future business and to remove materials supply uncertainty.

The lead time for increasing the supply of single crystal ingots and wafers is much less than that for polycrystalline silicon. Given a time period of 1 - 2 years, industry can increase its capacity to meet the requirements for single crystal silicon ingots and silicon wafers.

\section{B. RECESSION}

The recessions of 1970 and 1974 produced some interruptions in the growth of polycrystalline silicon use. Figure 1-1 shows the effect of these recessions. However, the recessions only caused brief interruptions in growth, with no long term effect. During the boom cycles prior to the 1970 and 1974 recessions, new polycrystalline plants were built. This new plant construction is not occurring now.

At mnst, a majnr resessinn will sause the projected cross-over of polycrystalline demand and supply to occur early in 1983. rather than 1982. The tight supply and consequently high prices of polycrystalline silicon will continue regardless of the depth of the 1979 recession. 


\section{SHEET SILICON GROWTH}

Processes being developed to grow polycrystalline silicon directly into sheet form could eliminate the silicon waste which results from sawing ingots into wafers. Sheet forms include Dendritic Web, being developed by Westinghouse Electric Corp, and Edge-defined Film Growth (EFG), being developed by Mobil-Tyco and IBM. Other processes such as silicon on a ceramic substrate are also being explored to reduce cost and silicon consumption. With these material processes, the potential exists to double the yield of solar cells from a given amount of polycrystalline silicon. Even if this is accomplished, the supply of polycrystalline silicon from 1980-1985 will not be substantially impacted since the shortage will still be caused by integrated circuit demand, not solar cell demand.

\section{DIRECTIONAL SOLIDIFICATION OF SILICON}

Solar cclls with 10 percent efficiency have been manufactured from semiconductor-grade polycrystalline silicon that has been directionally cooled in carbon crucibles. If this method of solidification replacen the Czochralski process, more polycrystalline silicon than forecast here would be required because the Czochralski solar cells are more efficient.

If a technical breakthrough occurred in the direct arc process to allow manufacture of relatively pure polycrystalline silicon for solar cells and this method was coupled witll the directional cooling process, then the need for semiconductor-grade polycrystalline silicon for solar cells would no longer exist. The potential for such a breakthrough exists and many companies are doing research in this area. However, the probability is that for 1980 - 1985, the Czochralski process will still be dominant.

\section{E. OTHER PHOTOVOLTAIC MATERIALS}

Highly. efficient solár cells are being manufactured in limited quantities from gallium arsenide, gallium aluminum arsenide and other more esoteric materials. 'l'hese materials are direct energy band gap semiconductors. As a consequence of this, very thin films of the materials can exhibit high solar cell efficiencies. The manufacturing technology for such cells is not yet fully developed and until this occurs, use cannot become widespread.

Cadmium sulfide solar cells have as long a history as silicon solar cells. The potentials for cadmium sulfide cells are in their thin-film character and potential low cost. The deficiencies lie in their low efficiency and reliability. Low efficiency cells are stable but not economical. High efficiency cells are potentially economical but not stable with time. If great technical progress in efficiency and stability occur, these cells have the potential for widespread future.' use. 
F. SOLAR CONCENTRATION

Viable concepts include improvements in collection efficiency and enhancement of available solar energy with the use of mirrors and lenses to concentrate the sunlight on specially designed silicon or gallium arsenide solar cells. The concentrating system can be cost-effective if the lenses and mirrors are manufactured at a lower cost per unit area than flat-plate solar cells and if the cost of special concentrator cells is not prohibitive. Present solar concentrator concepts indicate that requirements for silicon materials can be reduced by a factor of 50 for applications suited to tracking concentrators. However, residential and other non-tracking applications which are expected to be the bulk of the early photovoltaic market will continue to require the quantity of silicon material shown in this report for use in flat plate solar arrays. 
Section VI

CONCLUSIONS

Committee conclusions from analysis of the data obtained in industry interviews and discussions are:

There is high probability that a shortage of semiconductor grade polycrystalline silicon will occur by the end of CY 1982. The reasons given for this forecast are sumnarized as follows:

1. Undiminished growth of the integrated circuits industry caused silicon use to double frnm 1.977 to 1979 , and high growth is forecast to continue.

2. No significant effect on the long-term demand for semiconductor-grade silicon is expected from an economic recession which may take place in the 1979 to 1980 period. This conclusion was based on a history of the effects of previous recessions on silicon demand.

3. It is highly unlikely that the industry will invest in new silicon production plants which are based on the presently used Siemens-process. The main arguments against such new installations are: (a) The total product cost of silicon from new Siemens-process plants would be significantly greater than from existing plants (which were installed in the 1967 to 1974 period and are mostly depreciated). Higher costs would probably necessitate commensurately higher prices to allow for an acceptable profit and a reasonable write-off time. That adequately high prices will occur at the appropriate times to make investments in new plants commercially feasible is too uncertain to encourage plans for these installations. (b) Progress has been made in developing new processes to produce low cost, sericonductor-grade silicon. Hence, the likelihood that a new process will be used in silicon production plants about 1986 leads to a reluctance to illvest in Siemens-process new plants.

- Persistence of present market conditions will result in a strong sellers market by the end of CY 1981. The price of polycrystalline silicon will remain determined by competition within the semiconductor devices industry. 
- Some capacity expansion of existing plants is possible (up to $20 \%$ expansion at a moderate increase in price). This will only delay the projected polycrystalline silicon material shortage by a few months.

- The silicon requircments to meet PV demand called for in the Solar Photovoltaic Energy Research, Development and Demonstration Act (Public Law 95-590) dated November 4, 1978 would necessitate polycrystalline silicon in rapidly increasing quantities. The quantities of polycrystalline silicon required to support the production growth for two advanced solar cell fabrication approaclies against the anticipated available supply are shown in Figure 6-1. Unless the polycrystalline industry spearheads new production techniques and processes to increase its capacity within the next 12 montlis, implementation of Public Law 95-590 will require government involvement in sponsoring an expansion of the polycrystalline silicon production capacity.

Advanced thin-film based photovoltaic materials and cell processes will not likely be ready for application in the time period of interest to this study. Thus, the photo- ! voltaic materials demand projections herein are based on single and/or cast polycrystalline silicon solar cell technologies.

New technologies developed under the Low Cost Solar Array Project to produce low cost polycrystalline silicon will not result in available commercial plant capacity before 1986 under the present schedule in Figure 6-1.

- Single crystal ingot:growing and wafer slicing plant capacity is and will remain in balance with the needs of the users, and it will continue to expand. The acquisition lead time necessary for crystal growers and wafer slicers is relatively short at one year, so that no photovoltaic programmatic actions are necessary to increase volume capability. The present LSA process improvement work will be used in industry as each new technology item becomes fully demonstrated (such as multi-blade saws).

The develuping photovoltaic industry and the scmiconductor device industry prefer to use the vertical integration approach to remove materials supply uncertainty.

Conditions which could modify the projected shortfall in silicon supply include a more rapid advance than is presently envisioned in ribbon growth technology. This would reduce the quantity of polycrystalline silicon consumed in ingot growing and slicing processes. Silicon device manufacturers could add additional polycrystalline capacity to their present capability to assure sufficient materials for their 
own device needs. This could release material for solar cell manufacturing. Also, polycrystalline silicon suppliers may elect to expand their existing facilities through process modifications. Other polycrystalline users may decide to begin manufacturing their own material for assured supply and potential cost advantages. Many plans which are proprietary within each affected company could impact future silicon availability; but for the present, it is necessary that any procurement planning consider the potential of a silicon shortfall in 1983 and beyond.

The consensus was that growth of the solar photovoltaic industry as potential supplier of appreciable amounts of the nations's electrical power depends upon substantial progress from 1980 to 1985 in technology development and transfer and in the early installation of photovoltaic systems. The majority of government-funded demonstration projects are also likely to be built during this period. The common need is for the availability of a sufficient quantity of polycrystalline silicon at a low price. The consensus was that meeting this need was absolutely required to create the economic conditions necessary for the dovelopment of a solar photovoltaic industry. 


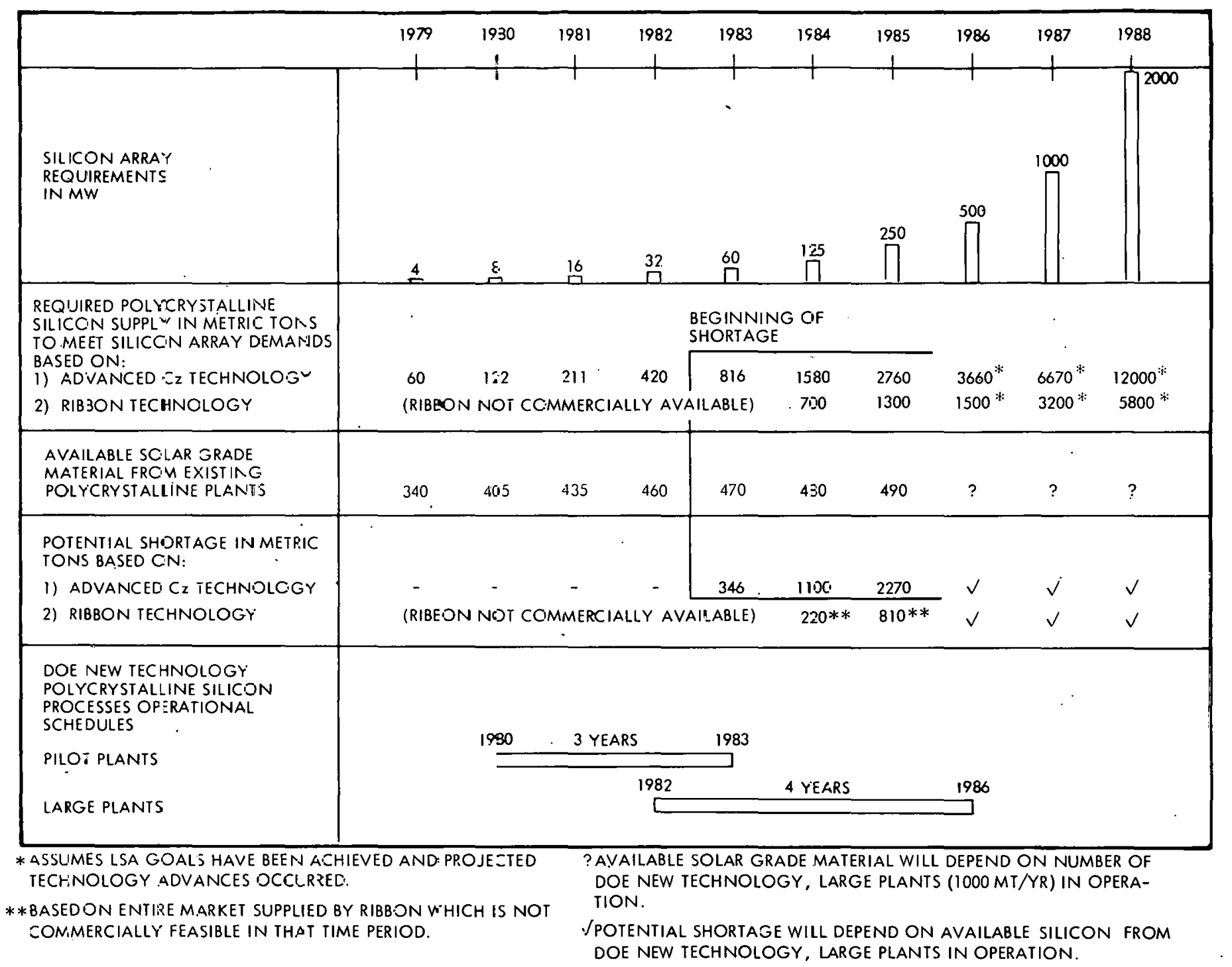

Figure 6-1. Silicon Supply Scenario for the Solar Photovoltaic Energy Research, Development and Demonstration Act (Public Law 95-590) dated Nov 41978 


\section{SECTION VII}

BIBLIOGRAPHY

1. Snyderman, N., "Fear Solar Cell Development Cutting Into Semicon Mfrs.' Silicon Supply," Electronic News, pp.1, 60-61, March 19, 1979 .

2. Kelemen, D.G., U.S. Patent No. 2,985,519, May 23, 1961.

3. Theurer, H.C., U.S. Patent No. 2,901,325, August 25, 1959.

4. Bishoff, F., DBP 1102117 and 1140549 (Filed 5-18-54).

5. Yaws, C.L., et. al., "Polysilicon Production: Cost Analysis of Conventional.Process," Solid State Technology, pp. 63-67, January, 1979.

6. Snyderman, N., "See Poly Supply Becoming Tighter," Electronic News, p. 50, July 23, 1979.

7. Feasibility of Low-Cost, High Volume Production of Silane and Pyrolysis of Silane to Semiconductor Grade Silicon, Quarterly Report, Union Carbide, Contract Report DOE/JPL 954334-78/7, April - June, 1978.

8. Evaluation of Selected Chemical Processes For Production of Low-Cost Silicon, Quarterly Progress Report, Battelle, Contract Report DOE/JPL 954339-78/11,12, Apri1 1 - September 30, 1978.

9. Ciszek, T.F., et a1, IBM J. Res Develop., Vo1. 23, No. 3, May 1979

10. Electronics, pp. 106-126, January 4, 1979.

11. Semiconductor Information Services, Second Annual Seminar, 1979

12. Gold, M., "U.S. Factory Sales of ICs Jump $32.3 \%$ to $\$ 3.2 B$ in '78," Electronic News, p. 47, March 19, 1979.

13. "See Power Sources Outlay Up 50\%," Electronic News, p. 42, June 25, 1979.

14. "The Superchip: Vast Computing Power is Foreseen As Ever lore Circuits are Packed on One Tiny Part," Wall Street Journal, p.1, April 27, 1979.

15. "Int'l Rectifier Sets $\$ 7 M$ Facility to Make MOSFETs," Electronic News, p. 20, July 30, 1979. 
16. "Exxon's Takeover Bid is Called a Bold Stroke But is Politically Risky," Wall Street Journal, p. 1, June 12, 1979.

17. "From G.E.," Business Week, p. 35, June 25, 1979.

18. "The Microelectronic Revolution," Metals and Materials, p. 20, March, 1979.

19. Waller, L., "Discretes Show New Life," Electronics, p. 90 , July 5, 1979.

20. "Arco Solar Plans to Produce Photovoltaic Modules," Electronic News, July 2, 1979.

21. Snyderman, N., "Fear Worse Squeeze in Polycrystal Silicon," Elcetronic News, pp. 1, 34, July 2, 1973.

22. Snyderman, N., "See Poly Si Shortage Abating," Electronic News, p. 76, September 10, 1973.

23. "Users Stretching Silicon Supply," Electron1c News, p. 57, February 11, 1974. 
In response to DOE concerns of a tight market and projected shortages in silicon supply, JPL TD\&A Lead Center organized a team to. investigate the semi-conductor grade silicon and wafer supply outlook from 1980 to 1985. The team was assembled by the Lead Center.TD subprogram, employing personnel from the field centers and consultants best qualified and prepared to investigate the issues. The team organization was as follows:

Mr. Walter A. Hasbach

Mr. Ernest N. Costogue

Mr. Don B. Bickler

Dr. Dennis Costello

Mr. Larry N. Dumas

Dr. Robert R. Ferber.

Mr. Brian D. Gallagher

Dr. Ralph Lutwack

Mr. David W. Moffett

Mr. Andrew Morrison

Dr. Remo Pellin

Mr. Charles Radics

Dr. Edward Sabisky

Mr. Paul Stella

Dr. Tom Surch

Dr. Car1 Yaws
JPL Team Chairman

JPL 'leam Organizer, Coordinator

JPL Team Member

SERI Team Consultant

JPL Team Member

JPL Team Consultant

JPL Team Member

JPL Team Member

JPL Team Member

JPL Team Member

JPL Consultant Team Member

JPL Team Member

3ERI Team Cunsultant

JPL Team Consultant

SERI Team Consultant

JPL Consultant Team Member

(Lamar :University) 
The study objectives adopted by the team cognizant management personnel were:

(1) Assess present and near term (1980-85) industry capability to supply (a) polycrystalline silicon material, (b) single crystal ingots, and (c) silicon wafers to meet the legislation proposed by Congressman McCormack.

(2) Obtain manufacturer's opinion of the silicon market demand of the $1980-85$ period.

(3) Identify potential alternate approaches to meet projected silicon solar cell demand if industry capability is insufficient.

The team approach was to review available data on the silicon material supply from interviews by SERI and other DOE organizations and to perform additional interviews with appropriate industrial experts in each segment of the silicon industry. Two teams were organized to conduct industry interviews (a) the polycrystalline silicon material outlook team and (b) the single crystal ingot and wafer team. All interviewing teams had a predetermined list of questions. The members of each interviewing team were:

\section{Polysilicon Material Team Single Crystal Ingot $\varepsilon$ Wafer Team}

$$
\begin{array}{ll}
\text { Dr. Ralph Lutwack } & \text { Mr. Ernest Costogue } \\
\text { Dr. Remo Pellin } & \text { Mr. Brian Gallagher } \\
\text { Dr. Carl Yaws . } & \text { Mr. David Moffett } \\
& \text { Mr. Andrew Morrisun } \\
& \text { Mr. Charles Radics }
\end{array}
$$

The team conducted the interviews through visitation and/or teleconferences. Inputs and data were solicited from a number of silicon material industries to assess the present and future industry capability. All the data obtained were kept confidential and were only used to generate the overall picture of the silicon material supply outlook from 1980-1985. The industries contacted are listed below. 
A. COMPANIES VISITED BY POLYSILICON MATERIAL TEAM

Interviewed

1. Hemlock Semiconductors, Inc.

William May - President (A Subsidiary of Dow-Corning Corp.) Hemlock, Michigan 48626

Bill Gregory - Plant Manager James McCormick - Research

2. Wacker Chemica1 Corporation 964 Third Avenue

Vern Meissner - Vice

New York, New York 10023

President (212) 421-7033

3. Electronic News

$7 \mathrm{E}-12$ th Street

Nat Snyderman - Editor, Materials

New York, New York 10003

(212) 741-4226

4. Montedian ALSA, Inc.

Smiel Silicon Products

10050 North Wolfe Road

Suite 293

Cupertino, California 95014

Tom Schauf - Marketing Manager

Russ Townsend - Area Sales Manager

B. COMPANIES TELEPHONED BY POLYSILICON MATERIAL TEAM

1. Texas Instruments Corp.

Dallas, Texas

2. Monsanto Company

800 North Lindbergh Blvd.

St. Louis, Missouri 63166

(314) $894-1000$

3. Great Western Silicon

11515 East Riggs Road

Chandler, Arizona 85224
William Haynes - Manager
Sales, Materials

Harold Patton - Director Long Range Planning, Electronics Division

Leo Rogers - President 
4. ARCO Solar

Chatsworth, California

5. Motorola

Phoenix, Arizona

Interview by Carl Yaws
Bill Herber - Vice President

Howard Klink -

C. COMPANIES WHICH RECEIVED QUESTIONNAIRES FOR Si SINGLE CRYSTAL INGOTS AND WAFERING INTERVIEWS AND PROVIDED DATA TO THE TEAM

1. Varian/Lexington Vacuum Division

121 Hartwe11 Avenue

Lexington, Mass. 02173

Mr. Dan Kostelein, Marketing Dept.

2. P.R. Hoffman Company

321 Cherry Street

Carlisle, PA 17013

$\mathrm{Mr}$, Al Shepts

3. Sawyer Research Products, Incorporated

35400 Lakeland Blvd.

Eastlake, Ohio 44094

Attn. Mr. Garry Johnson

4. Hamco-Kayex

I000 Millstead Way

P.0. Box 8920

Rochester, New York 14624

Attn. Mr. Pete Robson, Genera1 Manager

5. ARCO SOLAR

20554 P1ummer street

Chatsworth, CA 91.311

Dr. G.F. Wakefield

b. Siltec Corporation

3717 Haven Avenue

Men lo Park, CA 94205

$\mathrm{Mr}$. Antony C. Bonora

Vice-President Research \& Development 
7. Silicon Technology Corporation

48 Spruce Street

Oakland, New Jersey 07436

$\mathrm{Mr}$. Peter Aharonyan

8. Wacker Chemical Corporation

964 Third Avenue

New York, New York 19922

Mr. Vern Meissner, Vice-President

9. Monsanto Commercial Products Company

3400 Hillview Avenue

Palo Alto, CA 94304

$\mathrm{Mr}$. Antony H. Sweet

10. Motorola Electronic Material Group

P.0. Box 20911

5005 East McDowell Road

Phoenix, Arizona 85036

Mr. Terje Eek, General Manager

11. Cincinnati Milacron Company

Semiconductor Group

Route 48 and Mason Road

Lebano, Oh1o 45036

Mr. Michael Swantko

Marketing Manager

12. Smiel

10050 Wolf Road, Suite 293

Cupertino, California 95014

Mr. Tom Schauf

13. N.B.K. Corporation

3010 0lcott Street

Santa Clara, CA 95051

Mr. Shared Patel, Sales Manager

14. T.eyhn1d-Heraeus Vacuum Products, Incorporated

120 Post Road

Enfield, Conn. 06082

$\mathrm{Mr}$. Dieter H. Sundiermeyer

Product Manager 
15. Fluoroware Corporation

Johnathan Industrial Center

Choske, Minn. 55310

Mr. Don Quernemoen

Vice-President 
APPENDIX B

\section{QUESTIONNAIRE}

Industry's Ability to Supply Ingot \& Wafers

Czochralski Ingot Production \& Wafering Capability

1. Raw Material Availability and Grade

a) How difficult is it to get poly

Now? (how much)

Future?

b) What is the cost

Now?

Projected in future?

c) Is there another grade of silicon other than semiconductor which can be used?

Solar grade?

2. Throughput Capability

a) Production rate

b) What diameter/thickness $\mathrm{CZ}$ wafer is expected in future?

What time frame?

c) What is current price, $\$ / \mathrm{cm}^{2}$

Sawed?

Lapped?

Polished?

d) What is projected price in $1982 \mathrm{~s} / \mathrm{cm}^{2}$ ?

Sawed?

Lapped?

Puldsled? 
e) What is the projected price in $1986 \$ / \mathrm{cm}^{2}$ ?

Sawed?

Lapped?

Polished?

3. Production Problems

a) Yield

b) Impact of diameter \& thickness of wafers

c) Spare units

d) Recovery timc

e) What sawing technique is most successful?

f) What types of damage experienced?

4. Order Backlog

Present order backlog?

Anticipated in future?

Is it practice to maintain order backlog?

Is it practice to maintain warehouse stock on hand? How much?

5. Planncd Expanoion

What is the projected expansion?

Higher throughput?

Larger ingot manufacturing? How large?

Melt replenishment?

Sawing technology changes planned?

6. New Equipment Orders
a) What type? Manufacturer?
b) Delivery dates?
c) Cost? 
7. New Growth in Industry
a) New companies being formed
b) Competition
c) Other related industries (Quartz)

8. New Process Potentials

New crystal growth systems such as mold casting.

Low Cost Solar Array project developments impact on expansion.

9. Contracts on Other Incentives to Boost Production
a) How well are you equipped to meet projected DOE solar cel1 procurements?
b) Preference on bulk or staggered prócurements?
c) Long range procurement contracts - are multi-year purchasc orders desirable?


5230-1; Rev. A

DOE/JPL-1012-33

Photovoltaics Program

Distribution Category UC63b

Technology Development and Applications

Lead Center

\section{Silicon Materials Outlook Study for 1980-85 Calendar Years}

November 1, 1979

Prepared for

U.S. Department of Energy

Through an agreement with

National Aeronautics and Space Administration

by

Jet Propulsion Laboratory

California Institute of Technology

Pasadena, California

(JPL Publication 79-110) 